\title{
Narrative (re)Constructions: Reading the Formation of Contemporary Istanbul
}

\author{
Alexa Liedke \\ University of Virginia \\ Department of Middle Eastern Languages and Cultures \\ Master's Thesis, Spring 2017
}


For Gillian, Joe, Defne, and Refika

In each your own ways, you've all helped me so much.

I'll never be able to thank you each enough,

But I'd like to think that this is a start. 


\section{Table of Contents}

Introduction

Embodied Form and the Scalpel of Ideology

Transcendental Geometries of Power........................................... 8

(Post)Imperial (Re)Orientations.........................................13

(Post)Colonial (Re)Territorializations.........................................18

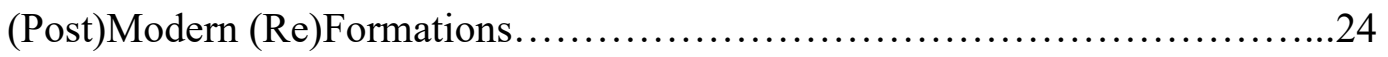

Ideology and the Socio-Spatial Dialectic...................................29

Disciplinary Heterodoxy and "Islamic" Urbanism..................................33

Reading Istanbul

Locating Istanbul, Contextualizing Ottoman Urbanism..........................37

Becoming-Oriental, Becoming-Peripheral: Istanbul at the End of Empire.........49

Becoming-National, Becoming-Local: Early Republican Istanbul................60

Becoming-Open, Becoming-Conflicted: Istanbul at the Crossroads..............69

Becoming-Global, Becoming-Fractured: Contemporary Istanbul Emerging......75

Concluding Remarks 


\section{Introduction}

Veritable palimpsests of memory, desire, narrative, and institution, the entity of the city and the condition of the contemporary can hardly be defined within a single measure or understood through a single matrix. From this statement, the city of Istanbul is by no means exempt. Layered on, in, and under the hills, it has seen the rise and fall of three empires before becoming the self-conscious cultural and economic center of the modern Republic of Turkey. At the crossroads of continents, of conflicts, of contemporaries, it defies binary definition. Sprawling ever outwards and consuming itself from within, it defies both boundedness and navigation alike. In short, the condition of Istanbul in the contemporary- like that of Turkey, like that of the Middle East, like that of the Global South at large - is complex. By virtue of the legacies which it embodies, the memories which it holds, the systems by which it functions, the wills by which it has been wrought, Istanbul is a site of multiplicity.

The question, then, with which I intend to grapple through this project is not of "why", but of "how" - how to approach the urban, how to connect the abstract to the concrete, how to write about multiplicity without getting lost in it, how to theorize without broaching on the essential. Though to presume my own ability to necessarily accomplish any of these be a declaration of incredible ego, this project is an attempt to do so none-the-less through the synthesis of a framework with which to approach understanding the relationship between space, place, narrative, and power within the conditions of the (post)colonial, (post)imperial, and (post)modern by means of excavating the conditions productive of the manifest contemporary. 
Moreover, it will seek to apply this frame to the condition of the urban embodiment of multiplicity - here, through the case of the emergence of Istanbul's present - by addressing urban (trans)form(ations) as a material and symbolic embodiment of the dialectic relationality between competing narrative imaginations and material conditions of identity and locality - the result of which is the ideological production of place.

Beginning with a discussion of the city through Spiro Kostof's "Organic Model", the purpose of this framework will be to attempt to follow the good advice of Edward Said from the 1995 reprint of Orientalism, wherein he called for the critical scholar to undertake the project of connections "histories of struggle" and "social meaning". In the interest of drawing connections, this theoretical framework - while critical itself of the utility of the (post)structural -will primarily rely upon that of Deleuze and Guattari's coauthored work Capitalism and Schizophrenia to discuss in the most abstracted terms the concrete mechanisms the concurrent institutional production of absolute socio-spatial segmentarity and universal temporal homogeneity, culminating in the willing-into-existence of the organization of space.

Through subsequent analysis of the conditions, narratives, realities, and legacies of the colonial and the imperial, focus will then be turned towards the literature of (post)colonial and (post)imperial theories of embodied subjectivity and geography in order to enumerate upon what Bell Hooks terms the fractured 'politics of location'. It will be argued here that this state of fragmentation characterizes not just the concepts of space, place, mobility, narrative, and identity, but is the result of what Edward Soja identifies as a dialectic relationality between these forces of the social and the spatial which produce manifest existence as a state of embodied legacy. 
It is from this theoretical position that the condition of Istanbul, as an urban locality within the "Global South", will be as a territorial embodiment of narrative and institutional will. Through analysis of the relationship between geopolitical position and social, political, and developmental histories, it will be argued that the people of Istanbul have been subjected to symbolically and materially violent processes for which the city has itself been subject, stage, and theater to the competing wills to (re)organization throughout the modern and postmodern eras. In that the purpose of this project is to posit an analysis of Istanbul's development in relationship to multiplicity - both that inherent of the urban sociospatial organism and of that particular to the city itself - this analysis will look to unpack the emergent impacts of orientalism, nationalism, (neo)imperialism, and (neo)liberalism. Not unlike the embodied subjectivity of the postcolonial subject, this analysis will look at Istanbul not through the lens of a unique or inherent essence but through that of its social and material having been formed relationally. In agreement with these theorists, the analysis posited here will argue that place, space, and identity alike within contemporary Istanbul have been ideologically constituted at the crossroads of a multitude of competing narrative imaginations. 


\section{(Em)Bodied Space and the Scalpel of Ideology}

In his work The City Formed, famed architectural historian Spiro Kostof articulates the city as both a place and an artifact - a testament to the material practices of organized human existence in territorialized object(ivity) (Kostof, 9). Through analyzing the design practices occurring at the juncture of geography and social history in both this piece and its partner, The City Assembled, Kostof explored the nature of the geometrical to urban formation - the efforts of which begin with a critical analysis of the manifestations Kevin Lynch's "normative" archetypical models of urban form: the cosmic, the practical, and the organic (Kostof, 15). This historical perspective explores the contradictory design matrix produced by the impetus towards geometry and the desire for an urbanism that is both sanitized and nostalgically "naturalistic" within the modernist imaginations of the urban, particular focus is placed on the organic and the notion of urban organization via material structure. As such, while paying particular attention to the organic model, Kostof discusses the contradictory relationship between Eurocentric planning ideologies and the urban 'organism' in reference to the false binaries of "planned" versus "spontaneous" and the patterns of geometric versus organic. This approach to urbanism and architectural history places the form and aesthetic of the urban body in conversation with narrative memories of urban experiences, social and institutional history, and topographical and geological factors as mutually determinant of development patterns (Kostof, 47).

Though within the context of this work, Kostof's analysis maintains significance through its discussion of urban in reference to the relationship between the social and the body via the faculties of metaphor and perception (Kostof 15). It is this nexus of forces which herein shape the urban that allows the argument to be made that that the city- as an embodied organism - is 
actively shaped by specifically located cultural narratives and socio-political institutions which conceptualize and reify the nature of self, personhood, and the physical existence of the personified self within space. In order to unpack and expand upon this extension of Kostof's allegory of the urban organism, I will here address his assertions of the nature of urban (re)form(ation) in order to argue that, through existing in a state of constant contest, these sociocultural imaginations of the embodied subject are continuously (re)articulated through patterns of transformation and (re)development. As such, the following framework will be broken itself into three sections - the first positing the city as a specifically territorialized place, the second analyzing the (post)colonial, (post)imperial, and (post)modern city through narratives of the body, and the third discussing the role played by ideology and its functions through law in mediating the relationship between the state, society, and the particular manifestation of urban space.

\section{Transcendental Geometries of Power: Stasis and Segmentarity in $A$ Thousand Plateaus}

Kostof defines the city first and foremost as a place which is in which value, investment, and specialization are "built up", whether in an instance of intentional construction or gradually over time (Kostof, 38). This centralization of value, be it material or symbolic, and investment, be it capital or in terms of population growth, insinuates that a city materializes as such through both the facilities of the physical and the imaginary. In addressing urban formation at the level of physicality, Kostof identifies plan, land use pattern, and building fabric as determinant factors of the process at hand (Kostof, 52); however, in conversation with the issue of topography and 
political geography, the amalgamation of these forces is the production of urban place as an iteration of territorialized locality.

In A Thousand Plateaus, the second volume of Capitalism and Schizophrenia, Deleuze and Guattari postulate that the primary function of the state apparatus is to generate and maintain territorialized stasis (Deleuze and Guattari, 362). Per their analysis, regimes of power function as abstract machines which produce dominion through the leveraging of concrete assemblages of domination the results of which are static habitats of power. These concrete assemblages materialize through the employment of a tripartite system of divisionary tactics which, historically, have worked to bind the conceivable extent of the world's inherent multiplicity in and to a state of stratified organization (Deleuze and Guattari, 502). As addressed by the authors, these strata - which, be they psychological, social, economic, political, or spatial, are themselves comprised of both content and expression - amalgamate in the genesis of "striated" reality, organized by, for, and through manageably segmented, concrete assemblages, to which the anarchic and perpetually-feared "state of war" is always external. Moreover, this project of partition is never fully complete; boundaries drawn by these transcendental geometries of power are constantly under internal and external stress and, as such, are constantly being reconstituted, rearticulated, and reified (Deleuze and Guattari, 354).

The first of these mechanisms of segmentation (and, by far, the most widely enumerated upon by critical, postmodern, and postcolonial theorists during the $20^{\text {th }}$ and early $21^{\text {st }}$ centuries) is the micropolitical construction of binary polarities of social identity (Deleuze and Guattari, 210). Rather than a project of wrote definition, binary striation is instituted by constituting certain categorical constructions of being as idealistically static or "molar" assemblages. It is around these molar building blocks that large-scale social systems with the aim of 
immobilization and territorialization are subsequently developed and deployed. By comparison, the diametric opposites of each molar particular - termed "molecular" - are fundamentally amorphous and are thus tasked with perpetually becoming categorical, calculable, and static (Deleuze and Guattari, 211). Furthermore, the boundary between each binary pair of molar and molecular is itself not strictly defined; rather, it is produced through relationality of the centralized characteristics of molar social entities to those of the molecular. By this dualistic logic, the rigid, molar categories of Man, of Bourgeoisie, of White, of Heterosexual, of Adult - if to name only a few examples drawn from the modernist imagination of the citizen- are juxtaposed with the fluid molecular categories of Not-Man, Not-Bourgeoisie, Not-White, NotHeterosexual, Non-Adult which, when pressurized to assemble within the conditions of the territorialized strata, become the embodied states of becoming-woman, becoming-black, becoming-proletariat, becoming-queer, becoming-child. The social result of this process is not similitude, but unity through manufactured relationality to the centralized ideal of the static subject (Deleuze and Guattari, 361).

The second geometric formation of concern is that of circular segmentarity. While not inherently singular, nor inherently bound to a single center nor inherently concentric, Deleuze and Guattari argue that the convergence of extant and potential centers to a single point - and the subsequent convergence of circular segments to concentricity - is a condition necessary for and necessitated by the modern state (Deleuze and Guattari, 210). This is not to say that these multiple centers of power or rounded segments disappear; rather, that within modern societies these apparatuses serve to organize resonantly the outgrowth of rhizomatic (read: non-static, non-central; ever branching outwards, ever at the crossroads) subject and spatial formations (Deleuze and Guattari, 211). While, without a doubt, the institutional centralization of political 
power within the modern state apparatus is an example of circular segmentarity, this particular mode of striation is also particularly adept for the analysis of space turn of these forces. In creating static subjects, this mode of segmentation nests the individual within a single home, a single neighborhood, a single city, a single municipality, a single state. While the actual boundaries of these units are elastic, this mode of territorialization still work to create a fixed spatial habitus in which the subject is invariably embedded; moreover, by this mode of territorialization, the spatial iterations of Michael Mann's forms of social power (political, economic, ideological, and military) are likewise mapped via center-peripheral relationality (Deleuze and Guattari, 435). This system thus works to produce both the spatial expanse of state as territorial, as well as to locate the citizen-subject therein.

The third of these strategies is the production of linear segmentarity. By this, the authors do not point to the literal drawing of lines, but rather the production of homogenized unitarity via invariant relationality between isotopic segments. This totalizing creation of a rigid, linear reason of progression allows for the totalization of systems of both concrete and abstract relationalities, as well as of the process by which these relationships transform over time (Deleuze and Guattari, 212). The example provided within the text is one of the linear relationality between wage labor, production, and consumable-goods, citing the methods by which capitalist systems of production - the goal of which is the mechanical production of consumable-goods -organizes both the experience of the subject through necessitating participation in both wage labor and commodity consumption (Deleuze and Guattari, 2013). Through this organization of the experiential, this example inevitably draws in the factor of time. While the experience of time as mediated by the routines of lived existence can be both linear and circular, capitalist modes of production have 
invariably necessitated the deployment of time that exists in linear uniformity for the sake of organizing labor as primarily a force of routinized production.

Not to be taken without a grain of salt, Deleuze and Guattari's attempts to theorize the methods by which the fluid comes under constraint inevitably fall into some of their own traps the results of which, in reading, often comes across as profoundly disjointed. Moreover, while useful for analyzing the rigidity of the modern state within the context of Europe itself, their original articulation of this schema of segmentation does not take fully into account the concurrent imperial formations outside of the European context during the early modern period, nor does it specifically provide insight into the transformative processes which preclude such systems as imperial conquest or colonial occupation. That said, the modes of production articulated here provide a useful vocabulary and framework through which to address colonial projects once they are put into active conversation with the writings of postcolonial and critical theorists whose works engage more directly with hegemonic narrative structures.

While conversations concerning the nature of the "real" have lost popularity within the social sciences since the turn of the century, confronting the ever transforming nature of power and domination requires critical (re)evaluations of the mechanisms by which nearly every aspect of the world and the modes by which we inhabit it are influenced by the grand narrative around which power revolves - in short, a critical evaluation of the realities in which we are nested regardless of the terminology which is applied. Important as it was to the theoretical developments of the postmodern movement, poststructuralism itself has received criticism in regards to its own inability or unwillingness to deal with aforementioned grand narratives, often to the detriment of the subaltern subject. In order to bridge this gap between the sanitized representation of reality offered here by Deleuze and Guattari, these mechanisms of 
segmentation must be removed from the contexts of both the abstract and the simply institutional - that is, these systems (as well as their authors) must be examined as themselves existing in relation to, and in conversation with, the complicated and complicating lenses of culture and geography.

\section{(Post)Imperial (Re)Orientations}

In his analysis of the urban organism, Kostof posits the Eurocentric model of the organic city as curiously "self-conscious" (Kostof, 52). Whether in the renaissance-influenced, neoclassical equation of streets with arteries and parks with lungs; the industrial metaphor of the financial sector as brain, the commercial district as heart, and the centers of factory production as limbs; or through the baroque nostalgia for the naturalistic, curvilinear townscape materialized in suburban planning schemes; Kostof notes the historical coincidence of these conceptualizations of the urban as a body with those of the shifting conceptions of the social body within the liberalhumanist ethos (Kostof, 53). This assertion - while critical in some regard - is further complicated upon analysis within the (post)colonial, (post)imperial, and (post)modern contexts. Further indicating the need to address Kostof's work through these perspectives is his claim that the archetypical organic city has been that of the "Islamic" city throughout history (Kostof 4748).

Absent an analysis of the role played by orientalism in the pathogeny of the organic model and admittedly essentialist in his characterization of "Islamic" urbanism, this statement is problematic at best; however, in conversation with the particular cultural narratives of the orientalist imagination, as well as their institutional and territorial manifestations, this assertion 
opens the door to utilizing the organic model towards a better understanding of urbanism within the territorialized, increasingly-global periphery during late- and (post)modernity. In order to facilitate this critical engagement, the purpose of the following section of this analysis will be to draw a connection between the emergent polarities apparent within the discussion of the social and the spatial, the culture and the institutional, the narrative and the material, the (post)structural and the subaltern, and the body and the myriad ecologies in which it finds itself embedded.

Articulated in Deleuze and Guattari's first volume, The Anti-Oedipus, the body exists as a unified biological machine - schizoid, yet not pathologically so - until which point its segmented, organ(ized) structure is willed into existence by force of egotistical delusion (Deleuze and Guattari, 9). While an adept analysis of the condition of the body of the molar subject within the imperial and colonial centers of western Europe, their theorization of the role played by will as strictly interior to the subject falls woefully short of including any consideration for experiential conditions of the (post)colonial or (post)imperial subject; moreover, their positioning of agency in/as rejection of structure is effectively marginalizing and silencing in its totalizing effect on subject for whom structure is an inescapable reality by virtue of biologically essentialized, narratively penetrating, and violently enforced cultural conceptions of class, gender, race, sexuality, and/or religion.

In her critical essay "Can the Subaltern Speak", Gayatri Spivak directly criticizes the centricity of the West itself as subject within the bulk of French poststructural theory as an attempt to produce a coherent narrative of will-power which, despite its global reliance on similar assemblages and techniques of domination, is so inherently diffuse that it defies totalization (Spivak, 66). Moreover, Spivak (correctly) states that Deleuze and Guattari, along 
with Michel Foucault, fail to acknowledge the narrative nature of ideology as parallel to its institutional nature and, in doing so, both abstract themselves from the arguments which they develop and absolve themselves from the real responsibility incurred by their positions as white, "western", male-coded scholars writing within the French academy (Spivak, 68; Spivak, 75).

In order to explore the extant relationship between narrative and institution, it must first be acknowledged that the role played by colonialism as a spatial, social, and definitively narrative projection of domination so integral to the creation of the "modern" world-system was as a violently rigid mode of territorialization exercised to create a geographically monopolar apparatus of European global hegemony (Wallerstein, 2). The result of these processes has been the embedding of assemblages of imperial dominion and domination within distinctive geographies of colonial violence. Iterations of rigid (re)territorialization, the myriad challenges posed by the cultural, political, and spatial (re)formations of the (post)colonial, (post)imperial, and (post)modern conditions produce both subjects and localities which embody legacies of narrative incoherence - both those levied upon the colonized and peripheralized by the competing political wills of the European imperial powers during periods associated with the production and maintenance of unidirectional global hegemony and those which have emerged as a result of the political, economic, cultural, and spatial conditions of challenge to this systemic domination.

While deeply interconnected in both theory and practice, it should be noted that colonialism and imperialism are themselves distinct phenomena. Imperialism, as defined by Edward Said in Imperialism and Culture, is the practice, theory, and attitudes of a dominating center towards its peripheral(ized) territories in establishing and maintaining an empire (Said, 9). Moreover, while imperial power is exercised by the state apparatus as a whole, imperial 
assemblages have historically been organized from, around, and to the benefit of metropolitan centers (Jacobs, 19). Rather than rigidly-bound to the territorial apparatus of the state, the position of these poles has been held throughout time by metropolitan urban areas as centers of production (material and cultural), focal points of mobility (both of materials, crafts people, and populations at large), and places in possession of symbolic significance through repeated material, cultural, and human investment and accumulation (Jacobs, 20).

Themselves the products of unequal distribution of power, privilege, and prestige, empires and their metropolitan cores works unilaterally towards self-reproduction via chains of capitalist production and consumption (Jacobs, 20). This process of continual centralization is maintained through the perpetual peripheralization of spaces and populations brought into the imperial domain - which is to say that in order to remain an imperial power, the metropole is perpetually engaged in the material and discursive (re)production of both imperial territory and imperial subjects. It is in this double bind which the territorialities and subjectivities of the imperial periphery are systemically (re)assembled to the benefit of the empire. Where the imperial center constitutes the polar locus of a spatial monopoly of goods, resources, and commodities - historically, of the production and profit therefrom; in recent decades, of consumption and profit therefrom - the imperial periphery is simultaneously relegated to the position of a tangible resource in and of itself and, therefore, available for exploitation.

While quite blatantly projects of circular segmentation in their internal dynamics via spatial centralization, it is the modes and chains of production and consumption which create linear organization within the context of empire. Addressed thoroughly within the context of European global hegemony in the works of neo/post-Marxist scholars of globalization such as Wallerstein and Polanyi, the particular role of political economy in driving this linearity far 
predates the context of capitalism. In her work Before European Hegemony, sociologist Janet Abu-Lughod posits the world-system of the $13^{\text {th }}$ and $14^{\text {th }}$ centuries as not only extant, but distinct in its organization as one of a multitude of spatially disparate poles connected through networked trade routes (Abu Lughod, 352). Though shifting political and ecological dynamics at the overlapping peripheries, the borderlands, of imperial influence mobilized vast transfers of population internally, imperial metropoles flourished simultaneously across Afro-Eurasia by means of constant engagement in the exchange of raw materials, manufactured goods, and craftspeople (Abu Lughod, 15). Not yet having converged upon a single geographic region, these inter-imperial relations - while dominated by specific routes such as the Silk Road, Mediterranean shipping lanes, and the Indian Ocean maritime trade - were not themselves yet subject to this linearity; however, the provisionary economies typical of early modern imperial assemblages served to linearly organize their internal dominions. Taxed often in kind, the early modern imperial subject's agrarian production of raw material was oriented linearly towards the center. Likewise, the craftsperson's production of goods, though often within a more urbanized and monetized context, was oriented towards the centers of trade and consumption which were embodied in both imperial metropoles and competitive port cities (Abu Lughod, 45).

This unidirectional flow of material towards the center worked similarly to produce the imperial subjectivities. While the rigid binaries of modern social stratification cannot and should not be retrospectively projected upon pre- and early modern imperial formations, the binaries of territorialized imperial subject versus deterritorialized nomad and the peripheral peasant versus the metropolitan elite are ones of fundamental significance. That is to say that, although the historical literature addressing pre- and early modern imperial subjectivities is severely lacking, it stands to reason that in the absence of colonial practices the depth of relationship between the 
imperial state apparatus was mitigated by proximity to the core due to the prioritization of spatial striation via material, financial, and symbolic centralization which has served historically as the hallmark of this particular assemblage (Jacobs, 16).

\section{(Post)Colonial (Re)Territorializations}

Violent by nature of the military element of territorial expansion, the territorializing assemblages of the imperial state apparatus detailed above - though engaged in the production of spatial, temporal, and subjective striation - have been articulated with the most vitriol and with the greatest extent and efficacy of socio-spatial penetration through the modern practice of colonialism. Defined by Said as a mode of imperial incorporation through invasion, occupation, and settlement, colonialization served as the dominant mode of imperial conquest by European states during the modern era (Said, 8). Both an ideological imagination of power relations and a concrete, material method of spatialized domination, colonialism has been directly responsible for the wholesale destruction of entire cultures and societies around the globe for the sake of capital gain.

Colonialism further accentuates itself from the broader category of imperialism through the pervasive and invasive reach of its primary ambition as one of the actualization of symbolic anthropological and geographical ideologies of supremacy. Thus, while similarly a mechanism of a transcendental project of boundary (re)drawing, colonialism and the practice of colonization constitute an inherently and essentially violent vortex of utter dehumanizing which render human and territorial bodies of the conquered alike to the state of fuel - objectified and commodified sources of potential energy, the abject consumption of which has powered the otherwise 
impossible project of materializing the world-view of white-western global hegemony (Woodward, 28). Though colonial enterprises of settlement and occupation were largely put to rest by the counter-colonial uprisings of the mid- $20^{\text {th }}$ century, the legacy of imperial-colonial fracture has not only remained intact, but active in continuing to destabilize the global landscapes of subjectivity and of political-economic development through to the present. As such, this discussion of these social and spatial formations of colonial domination will address these conditions as themselves continuous- if not static in their discursive and material constitution- throughout the (post)colonial, (post)imperial and (post)modern moments.

Further accentuating the dissonant nature of colonial enterprises is the justification of this systemic process of cannibalizing the ecologies, bodies, and cultures of the colonized by, for, and through the ideological matrix of post-enlightenment, liberal humanist ethics (Woodward, 59). While different empires rhetorically acknowledged this reality to different extents - the English, for example, preferred to view their empire as a rational "departmentalization" of production, as opposed to the French who appear to have been more overtly motivated by prestige -the relationship between the cultural politics which allowed for the creation and reification of a dehumanized conception of "other"-ness allowing for the total material exploitation of territories, cultures, and populations thereby relegated to a realm separate from the condition of "humanity" constitutes the ideological core of colonialism (Said, 169).

The juxtaposition of these internally competing ideologies and moralities both within the European imaginary itself and in the projection of the said imagination upon territories and populations subjugated via imperial and colonial projects has worked to produce narrative incoherencies across the proverbial board. This systemic deployment of European economic, military, cultural, and philosophical hegemony simultaneously fractured the subjectivities 
developing within the imperial metropoles by means of the codification of their own inherent hypocrisy and immobilized the colonial subject by means of necessitating the perpetual interiorization of imaginations and institutions of imperial power (Harvey, 2009; 39). As such, not only is it simply impossible to separate the seemingly contradictory forces of liberal ethics and colonial (terror)torialization; but, the narrative disjuncture produced by the constructed nexus of these apparatuses must be regarded as the machine by which the "fractured politics of locality" characteristic of both the colonial and the postcolonial conditions are (re)produced towards the ultimate end of an eternally and internally immobile subaltern (Hooks, 343).

Though decidedly apolitical (or, perhaps, anti-political) and lacking critical nuance in his analysis of the world outside of western Europe, French poststructuralist Michel Foucault is credited with delineating the techniques by which the seemingly-egalitarian moral, legal, and discursive institutions of the protestant ethic have been leveraged within the western European metropole towards an atemporal and inescapable subjugation of the first demonized, then pathologized internal "others" of the women, the homosexual, the child, and the criminal (Foucault, 1990; 104). Constructed at the intersection of universalist individualism and enlightenment rationalism, the liberal ethos of modernity is one in which the "will-toknowledge" in the form of the objectively quantifiable becomes the "will-to-power" through the negative classification of conditions of being deemed first immoral by faith, then irrational by 'objective' science; as such, resulting systems of oppression (as opposed to repression, in the Freudian sense) becomes the centralized institutionalization "will-to-control" within both culture and governmentality of elements constitutive of the internal other (Foucault, 1990; 94). Furthermore, the Other - as diametrically opposite to the human(ized) Self - is constantly sought out and solicited both interior and exterior to the subject psyche in order to perpetuate the 
workings of these technologies of domination through careful self-policing and, therefore, without direct surveillance or intervention (Foucault, 2012; 195). By this analysis, the ethical framework of liberal humanism manages to be both totalizing in its definition of the transcendentally uniform 'human' and decidedly oppressive in its ability to define certain traits, practices, or beliefs as determinant of full humanity (Harvey, 2009; 38). Within the context of colonialism, these discourses of rational, human 'self' and irrational, pathological 'other' facilitated within the European political imagination the moral rationalization of colonial domination as a civilizing, humanizing, and ultimately morally benevolent humanitarian mission in which formalization and control represented the liberation of the Other from their own backwardness (Harvey, 2009; 41).

In order to justify colonial domination and imperial exploitation of 'indigenous' populations, Said notes that this pathological condition of the other was applied wholesale to both the ecologies of location categorized as geographically peripheral to the territorial body of the European homeland as well as to the unitarily essentialized societies situated therein during their incorporation into the assembled body of the imperial polity (Said, 1978; 46). Through this socio-spatial centralization of the white-western self, the colonial apparatuses of modernity implemented globally the binary identity categories of European self-construction. Moreover, in doing so, the condition of 'indigenous' populations the world over was conflated to that of the racialized, feminized, (homo)sexualized, infantilized, and criminalized other. Judged 'empirically' by proximity to Eurocentric norms of appearance, behavior, and socioeconomic structure, indigenous subjects were addressed along a spectrum ranging from the immature (and, therefore, 'temporarily' unworthy or incapable of autonomous self-governance) to the demonic (and, therefore, too far removed from the 'light' of modern rationality to be realistically 
reconstituted as citizens of the empire) (Harvey, 2009; 39). That said, indigenous subjects across this spectrum of dehumanization were imagined as the object of the civilizing mission of colonial domination which serves the dual purpose of recoding the beliefs and practices of local culture at one end through the repeated trauma of abject physical violence intended to "season" the enslaved to a point of receptivity of their captive situation, at the other through more intricately symbolic methods of territorialized violence via occupation as well as discursive devaluation of extant cultural beliefs and practices (Woodward, 30). This systemic violence was done in order to incorporate the periphery into the productive body of the empire and further reify the European (and later, American) metropolitan delusion of divinely ordained, transcendent supremacy.

Given the regional focus of this thesis, it is the simultaneously infantilized, eroticized, and barbarized 'oriental' subject of the European imperial imaginations which holds greater pertinence. While subject to intense physical and material violence, particularly within occupied urban locations, the 'oriental' subject and the territorial expanse of the 'orient' were held within the orientalist imagination as objects of both fetishism and fear (Said, 2012; 17). It is the experiential embodiment of these contradictory narratives which is the primary concern of the works of Algerian sociology Franz Fanon who argues within his watershed work Black Skin, White Masks that the subjectivity of the colonial and postcolonial agent is forced therein to become one of anxious double consciousness. In that humanity and, subsequently, agency for the (post)colonial subject were contingent upon performative adherence to the normative modes and methods of selfhood brought by the colonizers, Fanon argues that the (post)colonial subject embodies a state of constant conversation with their own externally and internally perceived otherness - the constant negotiation of which results in a perpetual (re)othering of the 
(post)colonial subject regardless of the caliber of their performance (Fanon, 90). As a result of this constant (re)negotiation, the (post)colonial subject becomes an embodied palimpsest of the continued imperial and colonial legacies which they navigate at the levels of the geospatial, the narrative, the symbolically representational, and the political.

From the reification of this assimilationist scheme, poststructural literature is not exempt. In situating the Eurocentric subject as the focal point of analysis, poststructural thought has been widely criticized for stripping the (post)colonial subject of agency through the production of a theoretical totality of experience and the abstraction of subaltern identities from the politics of the material circumstances in which existence and experience are invariably embedded (Mohanty, 62). Moreover, according to Bhabha's critique within The Politics of Location, poststructural theorists presume a greater investment on the behalf of hegemonic discourse in the continual maintenance of domination (Bhabha 87). Echoing the Foucaultian discourse on the (here supposed) creation of systems of self-control, Bhabha puts forward that once satiated by colonial surplus the discourse itself addresses the (post)colonial subjects and localities with a certain ambivalence which allows for continual subversion - albeit within conditions of abhorrently uneven materiality between the two, as well as the existence in tandem of these amorphous subversions with the counter-colonial mobilization of rigidly essentialized (re)constructions of pre-colonial identities within the framework of (post)modernist hierarchies of power (Bhabha, 171). 


\section{(Post)Modern (Re)Formations}

As detailed by geographer Jane M. Jacobs in Edge of Empire, this relationship brought to the level of the state apparatus in the (post)colonial and (post) imperial condition between the self and the other produces a directly exploitative relationship between the Global North and the Global South wherein, the newly independent (post)colonial state is first articulated within the geopolitical structure of the nation-state, then (re)positioned hierarchically within the political and economic confines of the now-global periphery (Jacobs, 31). By virtue of these cultural politics, these techniques of imperial and colonial domination necessitate the anxious, internal (re)articulations of the same technologies of domination within the apparatus of the peripheral state through both the punitive threat of direct (re)colonization and the incentive of material and symbolic gain which would, in theory, translate to a shift in peripheral positionality (Wallerstein, 8). Put more concisely, the policy apparatus of the (post)colonial state incentivizes in much the same way as its colonial predecessor the embodiment of Fanon's so-called "double consciousness" of the (post)colonial subject - made both to perpetually police internal "otherness" and assimilate to normative metrics of modernization and development (Harvey, 1989; vii).

The joint result of this political and economic anxiety is the absorption - whether by force, incentive, or coercion - of (post)colonial states into a global system of narrative and physical violence against the eternally, internally sought-out Other, as well as the global system of capital accumulation which works unilaterally to (re)produce hierarchical hegemony. That said, in analysis of the socio-spatial and political-economic transformations of neoliberal globalization, it has become apparent that the success of this assimilatory project has not been one of reinstituting the concrete hegemony of the Global North - instead, the formerly 
nationalized spatial dynamics of hierarchical difference have been supplanted to those of the cosmopolitan concentration of uneven capital distributions. Moreover, this mutation of the organization of political, economic, and cultural power has created a rapidly accelerating, global situation of perpetual crisis (Harvey, 1989; 353).

Demarcated first and foremost by the deterritorialization of global financial capital beginning in earnest during the 1970s, the apparatuses of neoliberalism were assembled through first the notable decrease in the regulatory role played by the state in mediating the (then and now globalized) financial sector which was itself quickly becoming dominated by multinational corporate entities. From this political and economic shift emerged the ideological narrative of private success and private ownership as monikers of public progress and personal success - as well as the material-financial constitution of debt both necessary for speculative attempts at upward mobility and as a measure of invested potential (Harvey, 1989; 336). These economic developments have been paralleled by the remapping of the landscape of capital accumulation and commodity consumption from one of rigid centrality within the United States and Western Europe towards habitus within an increasingly competitive set of global cities - ascendant urban centers of financial growth, cosmopolitan culture, and perennial spatial sprawl - which stand in stark opposition to the shrinking state of the middle class and the decreased investment in rural (re)development that together appear symptomatic of a global (re)casting of class structure (Harvey, 2009; 51).

The combined political turmoil of the cold war and emergence of American (neo)imperialism throughout the latter half of the $20^{\text {th }}$ century which resulted in a state of near constant warfare at the global peripheries has, in addition to incurring a tremendous human cost, has mobilized mass migrations parallel in magnitude only to the concurrent rates of rural-to- 
urban population transfer. This wave of urban expansion, in combination with the demographic changes - forcible or otherwise - which occurred during the colonial and postcolonial periods and the economic, political, and geographic conditions of neoliberal globalization, has accelerated the fragmentation of the politics of place. This condition has taken form within the urban context in the exponential expansion of slums in and around cosmopolitan and metropolitan centers across the Global South (Parshad, 2017). While urban localities within the Global North have largely been exempt from the full effects of these migrations due to their geographical separation from the particular sites of conflict as well as the increased formalization within the legal framework surrounding land classification and use, informal construction and development has become the dominant vernacular of (post)colonial and (post)imperial cities within the (post)modern context. Paired with the rise of informal economies and the increased rigidity of global class structures, this trend is particularly disturbing in its coincidence with predatory abuses of power both at the hands of the state apparatus in the forms of corruption and police violence and at the hands of emerging parallel, non-state institutions for social, political, and economic organization (Parshad, 2017).

Aided, no doubt, by the tremendous technological advancement of the past century and inextricably tied to the political and economic chaos of the $20^{\text {th }}$ century, the compounding of these socio-spatial transformations has directly produced several critical (re)formations within this broader cultural renegotiation of local identity. The first of these conditions is the rapid growth of communities in diaspora. While the disruption of the ethno-linguistic homogeneity of the national polity is far from a negative facet of the contemporary, the growth of diaspora communities has been met with considerable violence at the hands of the state apparatus and intractable national imaginaries of static local populations alike (Jacobs, 32). As such, in tandem 
with the exercise of mechanisms of state violence pioneered during the colonial period against the external other of the occupied settlement against a quickly growing, internal, racialized lower class, the second cultural formation of significance to emerge through this period of globalization is that of populism (Ibid, 32).

Tainted with overt nostalgia for imperial grandeur - whether that of the colonial period, as has been the case in the United States and Western Europe, or the pre-colonial period as has been the case in the (post)colonial and (post)imperial periphery, such as those led by Modi in India and Erdogan in Turkey - cultural populism is quickly becoming a dominant, transnational political trend as (post)modern anxieties over both social and economic liberalism are actively mutating into (misdirected) anger (Parshad, 2017). This anger, levied on one hand with increasing violence against the internal 'minority' populations once championed by liberal rhetoric, is likewise being directed towards the third of these (re)emerging cultures of locality: cosmopolitanism.

Just as it would be laughable to argue that populism or diaspora are in any way new, the (re)formation of global cosmopolitanism is contentious largely due in part to the challenge which it poses to the fixed territorial formations of the nation-state as well as its direct relationship to the aforementioned economic conditions of neoliberalism. Per David Harvey's definition, cosmopolitanism is the deterritorialized class-culture defined by adherence to empty liberal humanism as well as particular patterns of commodity consumption including art, music, fashion, media, and food (Harvey, 2009; 53). Expanding exponentially in visibility representation due to accelerating income inequality and the growing role played by cosmopolitan taste in shaping commodity production and marketing, cosmopolitanism as a cultural formation is appearing with increasing frequency as both a symptom and a manifestation 
of a culturally homogeneous, global bourgeoisie - the harnessing of upward mobility towards which is increasingly incentivized by the mythos of neoliberal development policy and increasingly impossible due to the material reality of neoliberal economic policy (Harvey, 2009; 51).

Embedded within the striated spatial, cultural, and temporal formations of a (post)colonial and (post)imperial world, the challenge posed to the already fractured cultures and politics of location by neoliberal globalization does not a pleasant portrait of the future paint - the now globalized relationship between exploitative economic practice, political unrest, and the (re)entrance of ideological narratives entrenched in essentialized nostalgia to the political mainstream have every appearance of accumulating increasingly destructive momentum. Perhaps owing themselves to the gesturing towards a "frighteningly undifferentiated Otherness" by the deconstructive efforts of the (post)modern movement, anxieties over an unstable future are actively and publically intersecting with the manifest reality that past methods of creating a meaningfully located sense of self and community will only continue to lose efficacy as the already fraught cultural and socio-spatial politics of the neoliberal globalization press onwards (Spivak, 70). Moreover, even within scholarly studies of globalization, competing narratives of the condition of the contemporary offer no single clear direction for future study. Similar to Watts description of the phenomena of globalization, these (re)developments within culture, politics, and identity do not "signal the erasure of difference", but rather open the door to incredible multiplicity and expressions of difference (Watts, 10). Whether genuine or manufactured, the global territorialization of spaces of otherness is now and will continue to resist cohesive totalization. 


\section{Ideology and the Socio-Spatial Dialectic}

Law, as defined by (neo)Marxist scholar Louis Althusser in Ideology and the State

Apparatus, is the predominant ideological arm of the state in that it organizes the relationship of the individual to the state apparatus at both the levels of the imaginary relationship between them and of the individual's relationship to their own concrete, material conditions (Althusser, 181). Within the context of the emergence of capitalist modes of production within modern Europe, this relationship was defined first and foremost by the necessitation of universality and formality in order to facilitate and regulate the production, transportation, sale, and consumption of commodities (Althusser, 165). While far from inherently universal, this particular conception of the form and purpose of law was dispersed globally through European imperial and colonial projects which saw the formalization and codification of legal code across effected territories.

Within the context of the imperial this transformation was as much internally motivated by the impetus towards modernizations as it was externally motivated by the equation of informality with primitivism - a statement further justified by the direct mirroring of national constitutions produced by (post)imperial and (post)colonial states during bids for independence after those of the European center. That said, while the impossibility of complete formalization and universalization is impossible within any context, the particular relationship between codified law and its enforcement within the (post)imperial and (post)colonial is especially divergent - a state which indicated less a loose relationship between law and society in general, and more a loose relationship between the European legal ideal and societies in which the same ideal did not emerge organically. Per this definition, ideological power works within the (post)colonial and (post) imperial to produce not difference, but segmentarity. In and through the state apparatus, the ideologies implicit in facilitating the ascension of the European elite to global 
hegemony have attempted to create a universally totalizing condition in which both subaltern subject and their spatial-temporal loci are torn between the fundamentally incoherent narratives and institutions of power. Resulting in chaotic and fractured patterns of embodied development, territory, subject, and subjectivity are made to fill the roles of both soldier and battleground for the perpetual solicitation of the centralized "self" and peripheralized "other".

In articulating the emergence and (re)formations of the urban body as existing within the context of the relationship between law and society, Kostof's conception of the city is intractably tied to the concept and exercise of ideological power. To the contemporary complicating of territorialization, the role of urban locality has, for better or worse, been critical. Organized through legal articulations of land division, land classification, land use, and property rights, the spatial aspect of urban formation and embodiment are necessarily organized and mediated by the legal structure. This relationship between spatial embodiment - whether of the human or urban forms - and socio-cultural narratives and institutions constitutes what (neo)Marxist geographer Edward Soja terms the "socio-spatial dialectic". As described in his essay of the same name:

"The structure of organized space is not a separate structure with its own autonomous laws of construction and transformation, nor is it sim- ply an expression of the class structure emerging from the social (i.e. aspatial) relations of production. It represents, instead, a dialectically defined component of the general relations of production, relations which are simultaneously social and spatial” (Soja, 208).

As this assertion pertains to the cultural politics of location within (post)imperial and (post)colonial urban entities, the legacy of both the territory and the legal system is burdened with multitude legacies of symbolic and material violence, both at the hands of colonial powers 
and at those of national regimes which exercised similar methods of domination in their efforts towards establishing 'modern' statehood and competitive global political and economic positionality. In that this status as imperial subject is maintained largely through the ideological apparatus of codified law, the construction of imperial subjectivity serves to define and territorialize other forms and practices of identity by means of legal classification. By no means uniform, the nature of imperial subjectivity prior to European hegemony simply cannot be generalized; however, the project of legal classification is one which has been extensively theorized in relation to the production of molar modes of being through the allocation of varying levels of legal privilege, penalties, and responsibility along preexisting divisions of identitybased social stratification belonging to any particular society or culture that has been internalized by the imperial assemblage.

While the politics of international tourism within the context of globalization have placed impetus on the curation of whole cities as consumable commodities, it remains true that the material nature of signs, signals, and symbols of these legacies of (post)colonial and (post)imperial social, economic, and cultural striation are embedded and embodied within urban form, urban fabric, and the architectural object. Moreover, these material symbols and narratives which accompany them cannot be as quickly over-written or (re)coded the landscape of the city itself. That the processes of urban transformation and (re)development exist within this sociospatial dialectic is indisputably real; however, it is persistent trend towards entropy which posits a continual challenge to the ideals and ideologies guiding modernist planning schemes. Themselves the product of enlightenment rationalism and the particular obsession of Western European imperial powers with the legacies of an idealized and mythologized Roman and Greek heritage, the conflict between the prescribed formality of modernism and the actual processes by 
which development has continued in and in spite of this guiding ideology will be the subject of the remainder of this study. While evident within Major European cities, this socio-spatial disjuncture is particularly visible in (post)colonial and (post)imperial cities, wherein the division between formal and informal development patterns has led to a landscape fractured along the lines of socioeconomic class and communal identity alike. 


\section{Disciplinary Heterodoxy and the Study of "Islamic" Urbanism}

Identified by Kostof as the archetype par excellence of Lynch's organic model of urban form, the subject of an "Islamic" urbanism is nested within particularly fraught historical and cultural contexts (Kostof, 62). Though astute in his citation of the patterns by with Roman-era grids trended towards disintegration following their integration into an Islamic empire, the analysis posed by Kostof in relation to both the nature of Islam and the geopolitical locations in which Islam exerts influence remains incredibly reductive (Kostof, 48). Islam, quite simply, defies such totalizing characterization.

In discussing the spatial nature of Islam it must be noted that the faith, as the most recently emerging of the major world religions, stood to inherited much from its predecessors geopolitically both broadly and in terms of local vernacular. Born at the proverbial and economic crossroads of Africa, Europe, and Asia, the territorial expanses of the many imperial formations espousing Islam as their religion of choice have spanned from Mauritania to Indonesia. As the localities absorbed by the Caliphates and their successors are among some of the longest inhabited sites in the world - each with particular local cultures, religious beliefs, and legacies of empires past - the faith itself has historically been rather heterodox, with multiple schools of jurisprudence emerging and existing in combination with particular interpretations and practices of the faith - which is to say that the presumption of a uniform "Islamic" culture is laughably essentialist at best, and at worst a retrospective projection of modern Islam upon its past.

As this pertains more specifically to socio-spatial analysis, modern European scholars have done considerable disservice to the study of urban formation and urban identity within a state apparatus organized by the tenants of shari'a law. Not unlike Marx's assertion that the 
primary political-economic formation of the "orient" was that of the predatory despot, Max Weber's writing on the "Islamic" city posited them as the direct opposite of the rational, European model - monolithic conglomerates, lacking in civic culture and urban identity, which were both productive and emblematic of social fragmentation (Eldem, Goffman, and Masters, 2). This analysis, while utterly lacking in historical data, served as the predominant approach to Orientalist and Orientalizing approaches to the city within the so-defined geopolitical expanse of the Middle East. Though recent explorations of medieval urbanism, the relationships between shari'a and society, and Islamic art and architectural history have roundly disproved Weber's assertion of an Islam absent "urbanism", the fact remains that the discussions surrounding this literature are focused primarily within programs of Islamic and Middle Eastern studies and that it is overwhelming outside the scope of the late- and (post)modern (Mills and Hammond, 159).

The following section of this thesis will seek to address this gap within the literature, as well as the disciplinary division by which the gap has been facilitated, through a critical analysis of the socio-spatial dialectics at work in the emergence of (post)imperial Istanbul. Through the theoretical framework established here of the city as a territorial embodiment, this analysis will examine the relationship between the iterations of Istanbul's (re)development from the twilight of the Ottoman Empire through to the conditions of the (post)modern present as materializations of the competing narratives of the relationship between space, place, and subject as they have been articulated by and through the state apparatus of the Modern Republic of Turkey during what will soon be the century of its territorialized existence. Narrative and material multiplicity are not only central to the "character" of Istanbul; but the relationship between the state apparatus and the existence of internal multiplicity has been and continues to be the key to 
reading change as a constant factor of the late- and (post) modern conditions of the urban organism.

Though the case studies addressed herein will deal exclusively with the late- and (post)modern portions of Istanbul's long history, the complex social and political landscape of the Republic of Turkey cannot be entirely understood without reference to that of its predecessor, the Ottoman Empire, and the complex nexus political, economic, and cultural forces and narratives surrounding the birth of the Republic from the empire's ashes. This is not to imply that Turkey is some seamless continuation of an ancient (and oft romanticized) past; rather, that the Ottoman Empire's particular situation within world political and economic systems during its existential tenure influenced that of the Republic through the palimpsest physical and narrative legacies embedded and embodied in the shared territorial habitus of the Anatolian peninsula. As such, the case study presented below will begin by providing historical context on Istanbul's development under Ottoman rule. Far from themselves static, this historical context will pay special attention to the changing relationship between the Ottoman state apparatus, the Ottoman subject, and imperial territoriality

From its outset, Mustafa Kemal's republican project sought explicitly to distance Turkey from its Ottoman past as much as possible; however, to judge the success of this venture is not my purpose, nor my place. Following the aforementioned contextualization of Ottoman urbanism, the subsequent sections of this paper will examine four distinct periods of Istanbul's social and spatial (re) development: Tanzimat Era to the abolition of the Sultanate, the Early Republican period, World War II to the 1980 Military Coup, and 1980 Coup to the Present. In that the purpose of these cases is to examine the conditions of multiplicity and competition between imaginations of the citizen, city, and state, this breakdown intentionally avoid strict 
temporal bounds and looks instead at the emergence and institutionalization of significant discourses from a confluence of forces instead of a single moment. From this perspective, this study of Istanbul's development will look to the material transformation as the materialization of certain ideologies - reifying and reinforcing their own presence through layered transformations of aesthetics, fabric, and population - which are themselves produced by the tensions placed upon the city as the (former) imperial capital within the peripheralized, (post)colonial, (post)imperial state apparatus of the Republic of Turkey. 


\section{Locating Istanbul, Contextualizing Ottoman Urbanism}

Human settlement in the location now constitutive of the city of Istanbul far predates the Turkic migration to Anatolia, let alone any semblance of the tribal formation which would go on to become known as the Ottomans. Declared the capital of the newly formed Eastern Roman Empire by Constantine in $330 \mathrm{CE}$, the settlement known formerly as Byzantium became Constantinople - referred to first in official documents as "New Rome". This city space, populated to some extent by the Greeks for centuries, encompassed what is now the Istanbul peninsula - a series of seven colossal hills, each of which came in time to hold monumental importance; an ancient harbor; and a triumphant avenue parting to the east and west along which the forums were built - was encircled first by the Wall of Constantine and, later, the Wall of Theodosius (Mango, 17).

Growing in prominence and wealth due to its strategic location along the Black Sea, Mediterranean Sea, and trans-Asiatic trade routes, Constantinople's population grew exponentially during this period of roman rule; however, twice walled, the city was not able to horizontally expand past the $5^{\text {th }}$ century (Mango, 18). In order to accommodate this growth, the city's urban fabric was built up, becoming a complex maze of multistory tenements which overtook the majority of the space between Constantine's luxurious promenades and later testaments to the glory of the Christian God which came to adorn the hilltops (Mango, 19). Built primarily of wood and crowded so densely that roads were often less than 3 meters wide, massive swathes of the urban fabric formed by these complexes would burn down - by accident or by virtue of the earthquakes to which the area was prone - only to be rebuilt, time and time again (Celik, 18). After the $10^{\text {th }}$ century, in which foreigners were allowed to land concessions, these neighborhoods began to form distinct quarters within the peninsula - the exception of 
which being that of the Jews, disallowed from residing within the city's walls, who settled across the Golden Horn in Galata. Joined in the $11^{\text {th }}$ century by a community of Genoese merchants and, subsequently, fortified, Galata became a fully independent colony within the greater urban complex (Yerasimos, 25). It was this dense, polyglot metropolis - steeped in the Byzantine legacy and pumping the blood of Italian trade goods - which became the crowning jewel of the Ottoman Empire upon its conquest.

Originating a federation of Turkic nomads in north-central Anatolia with strong connections to the Mevlevi Sufi order active in the peninsula at the time, the sons of Osman rose to local prominence in the $14^{\text {th }}$ century after swallowing several rival beyliks (territories under the dominion of a given chief or bey) to the west and coming into the service of the ever flailing Byzantine empire in the form of military vassalage (Lowry, 22). Given the hypermobile dynamic of early ottoman society, relatively few records have been kept pertaining to their internal social structures and systems of political power; moreover, what few there are largely come from outsiders - be they in the form of travel narratives, such as that of Ibn Battuta's tour of the region in the early 1330 s, or in the writings of historians residing within sedentary states or cities with which the Ottoman armies came into contact. What historians do know about the pre-modern Turkic tribal societies is that the internal sociopolitical structure of their confederations - the Ottoman confederation included- was simultaneously highly patrimonial and highly diffuse, with the chief having a quasi-paternal relationship to the tribe, law being derived from the word of the chief in Turco-Mongol fashion, and succession being managed not by primogeniture, but the division of territorial acquisition between all legitimate heirs (Lowry, 43).

Though they had conquered much of western Anatolia during the 150 years prior, the Ottoman dynasty emerged as an imperial power in the truest sense with their conquest of 
Constantinople in 1453 under Mehmet II the Conqueror. Intended from the start to secure an imperial capital as well as to eradicate the Byzantine thorn in his side, Mehmet II's invasion of the city was not coupled with catastrophic structural damage typical of siege warfare at the time (Celik, 21). Inheriting the city as it stood, the influence of its chaotic Byzantine form (or lack thereof) remained until the modern era; however, the dense urban fabric was dramatically reoriented around a number of religious building projects aimed at transforming the former stronghold of Orthodox Christianity into a distinctly Islamic city (Celik, 22). The city was divided into thirteen quarters, or nahiyes, each of which was organized around a major kulliye, or mosque complex, the earliest example of which being the Aya Sophia, which was converted to a mosque upon the very day Mehmet II entered the city. During the reign of Mehmet II alone, 17 churches were converted to mosques and 173 new mosques, 24 mektep and medresse school complexes, 32 hamams (bath houses), and 12 hans (markets) - one of which was the central structure of what is now the Grand Bazaar (bedesten) - were built (Celik, 24). Situated atop Constantinople's hills, this reformation of the urban grain produced a pattern of circular development that was also mediated topographically by the physical and symbolic elevation of the Mosque Complex (Celik, 23).

Unlike the main city of Constantinople, Galata was offered a deal in exchange for surrender which allowed for the continued presence of a relatively autonomous life therein so long as additional taxes were paid to the Sultanate. In combination with the Ottoman's extant control over Silk Road trade through Anatolia and full maritime control over trade from the Black Sea, this settlement curried favor with the Venetian and Genoese merchants based in the settlement and allowed the Ottomans access to a sizable portion of the enormous trade fortune of the Galata (Celik, 22). As such, the taking of Constantinople allowed for full control over Black 
Sea trade and, once able to develop a competitive navy, massive influence over the already established trade empires of both Italian city-states. This boon to its financial status was enough to quickly catapult the Ottoman dynasty to the status of eminent Imperial power.

Just as the taking of Constantinople solidified the Ottoman's status as Imperial, the conquest of the city and subsequent territorialization of its ruling apparatus allowed for the emergence of a landed administrative system - a key component of which became an extremely sophisticated military-bureaucracy (Tezcan, 12). Along with this emergence of spatially centralized governing power came the codification of law, including formalized systems of land and product distribution, taxation, judicial administration, and community organization (or lack thereof). The legal stipulations put in place by Mehmet II's Kannuname, while of course subject to some change throughout the centuries, explicitly defined modes and methods by which the Empire operated until the Tanzimat reforms of the $19^{\text {th }}$ century (Tezcan, 11). Of these systems which guided the mechanisms of the state, several hold critical importance to the nature of Turkish society and politics to this day in its oppositional self-construction.

In stating that the geopolitical expanse of Ottoman territory was considered imperial patrimony, it must first be noted the effect to which the political construction and constitution of the royal household shaped the sociopolitical nature of the Empire as a whole. In order to avoid the fragmentation common within Turkic tribal politics due to the absence of a precedent for primogeniture, the early heads of the Ottoman household instituted an informal policy of fratricide amongst eligible sons of the Sultan. Critical to their early success, this use of fratricide as a means of determining succession in the absence of primogeniture became formally codified under Mehmet II in order to ensure that the sovereignty of the Sultan would remain permanently indivisible. While contest between sons verged on all-out civil war on several occasions, this 
practice ultimately led to nearly 600 years of unbroken dynastic succession - a feat entirely unrivaled in European history(Pierce, 1993; 6).

Following this theme of indivisible sovereignty, the practices of marriage which became the imperial norm were likewise solidified during Mehmet II's reign (Pierce, 1993; 28). The conquest of Constantinople brought about the fixed institutional and physical structure of the Imperial Harem as contained within Topkapi palace. Designed as a series of concentric courtyards, Topkapi Palace made manifest the notion of proximity as power. While virtually any subject with a relevant petition could enter the first courtyard up to "the gate of happiness", only members of the ruling council, the Divan-I Humayum, could pass through the gate and enter the sultan's waiting room known widely as the "golden cage". The areas of the palace past the Golden Cage, in the space considered officially the Imperial Harem, were exclusively reserved for the Sultan and members of his household. Prior to the construction of the palace complex, the Sultan had occupied the position of first among equals, often riding at the head of the army and eating dinner with his officers. This spatial sequestration of the Sultan's body along with those of his wives presented a clear delineation from the traditions of the past as the office of the Sultan moved from that of warrior-king to full-fledged Emperor (Pierce, 1993; 153).

It should be noted that, despite their position as property of the state and the Sultan, royal women within the Ottoman Empire were awarded phenomenal wealth and political clout throughout the tenure of this institution. One mode by which this influence was exercised was through the institution of the vaqf. Vaqf was the creation of a permanent, charitable trust encouraged among the extremely wealthy elite which, during this period of time, most often took the form of architectural patronage and property endowment (Pierce, 1993; 186). While relatively little archival material has been found detailing any imperial attention towards urban 
planning following Mehmet II's overhaul of Istanbul's urban fabric, a veritable wealth of paperwork exists on the individual buildings sponsored by members of the royal family and other wealthy notables (Singer, 4).

While prominent examples of this include those endowed by the sultans themselves, such as the vaqfs in place for the maintenance of Aya Sophia or the construction of the Mosque of Selim I, the overwhelming majority of the vaqfs endowed by members of the royal family are in the names of its female members (Pierce, 1993; 188). These endowments, which ranged from mosques to monuments to shrines to tombs, were no small projects - many of the structures designed and built by Sinan, the Ottoman Master Architect of the $16^{\text {th }}$ century, were commissioned and funded via vaqfs in the name of Sultan Suleyman's wives, sisters, and daughters. Moreover, the monumental nature of these projects worked to explicitly convey not just the wealth and social responsibility of the patron, but of the empire as a whole through their experimentations in form, extravagant décor (or lack thereof, in the case of the Suleymani Mosque), and their strategic and largely symbolic incorporation of spolia from Roman and Byzantine empires - as well as Fatimid Egypt following it's absorption in the early $16^{\text {th }}$ century (Necipoğlu, 172).

As mentioned above, the upbringing and training of future officials was a matter of the Imperial household itself. Started in the 1300s by Murad I, the devshirme or "blood tax" was the routine extraction by the state of young, non-Muslim boys deemed the best, brightest, or - as has been reported in some cases - more beautiful to be reared to specifically become soldiers or civil servants. The boys, known thereafter as Kul, were sent to rigorous institutional academies wherein they were instructed in the skills necessary to become high ranking bureaucrats, administrators, religious figures, and military officials. The majority of these soldiers were 
designated to the group known as the Janissary corps who, in addition to serving elite fighters during wartimes, served the state during peacetimes as ceremonial guards, firefighters, and police officers. Of the total members of the Kul, the cream of the crop - those deemed destined for the highest positions in the Imperial government - were brought into the Imperial Harem itself to be educated and to serve as members of the household by preforming duties directly for the sultan (Tezcan, 35).

The symbolic and practical value of the devshirme during the Empire's formative years cannot be understated. Ottoman society during this time was divided primarily between the askari, the administrative/military class, and the rest of the population, called the raya'a or the "flock". In addition to ensuring that state officials were groomed to processional perfection, this system ensured that a considerable percentage of the askari held loyalty to and only to the Sultan, a figure deeply paternal in connotation through his direct responsibility for not only the majority of their upbringing, but for provision of nearly every material comfort which they were allowed (Pierce, 1993; 33). In essence, this process worked to produce a population - if only $15 \%$ at its greatest extent - of perfect citizens, members of which held the overwhelming majority of the highest administrative and military positions in the empire besides the throne itself (Tezcan, 35).

The relationship between the Ottoman subject and the imperial state apparatus was organized primarily through the law as exercised through particular systems of spatial, administrative, and legal organizations. At its territorial height, the domains under Ottoman control stretched from modern day Algeria to modern day Iran and from as far north as Vienna to as far south as Aden, Yemen and Eretria - thus encompassing the extreme ethnic, linguistic, and religious multiplicity therein. In order to successfully administer this territory while minimizing 
the threat of peasant revolt or the reformation of conquered political entities, it was decreed that local religious and legal institutions zimmis, "people of the book", in Ottoman territory would be permitted to remain relatively autonomous in their governance of their own communities, while still being provided services such as military protection and controlled pricing of necessary goods, so long as taxes continued to be paid in kind and in full (Tezcan, 14). This system of religious communal autonomy was technically nameless until the $19^{\text {th }}$ century, at which point it was formally codified and named millet; however, many scholars apply the term retrospectively none-the-less. The parallel religious and legal institutions stipulated by the Millet system did not come without their own oversight in the form of imperially appointed judges for cases between religious groups, as well as a referral system to the central court in Istanbul for cases pertaining to the funds or property of the Imperial patrimony - one type of case referable for imperial review being that of abuses of power by local administrators (Tezcan, 15). These systems not only allowed considerable degrees of local autonomy within Ottoman territory, but did so with careful consideration for the maintenance of stability and accountability therein at the local level.

Outside of major urban centers the position of overseeing which was allocated in territorial parcels (timars) to local leaders, decorated soldiers, and individuals within the empire able to otherwise curry the favor the administration. Timar holders were kept in check by judges (kadis) similarly assigned by the central government. Internal to the capitol city both legal jurisdiction and municipal administration were organized through the office of the kadi of Istanbul (Seyhulislam) (Celik, 43). Originally a part of the Divan-I Humayum (head governing council of the empire), the Seyhulislam's role came to extend far beyond that of the judicial, including the organizing and orchestrating transitions of power between Sultans and administering the majority of the municipal functions of the city under the precedents set by 
Islamic legal and political theory, functioning effectively as "mayor, judge, and head of the municipality". Under the direction of the kadis, Istanbul itself was divided into four sections known as kadiliks (Istanbul, Uskudar, Galata, and Euyp) and administered according to the principles of Hanafi law, which allowed for considerable freedom of interpretation on behalf of the judges in dealing with individual cases and prioritized private rights to and uses of property over those of the public. As such, not only were the records kept of property ownership relatively sparse in the cases of non-elite families, but much development was allowed to happen informally - resulting in the building of higher and higher structures, the division of lands into smaller and smaller parcels, and the gradual encroachment on the already narrow streets (Celik, $51)$.

This relationship between the Empire's broad and highly sophisticated mechanisms of political power and the relatively minimal extent of its social power upon individuals and communities nested therein remained the basis of state governmental organization until the $19^{\text {th }}$ century. As such, while fueled by continual territorial expansion, the influx of funds, goods, and bodies to its capital fueled a massive population and development increase within Istanbul's walls. During the height of Ottoman imperial power during the $15^{\text {th }}$ and $16^{\text {th }}$ centuries, the population more than tripled - ballooning to between 700,000 and 800,000 by the mid-1600s (Celik, 37); however, while spatial expansion and total control over trade allowed for institutional and material growth during this time, the $17^{\text {th }}$ and $18^{\text {th }}$ centuries posed a challenge to the Ottoman system via the advent of European imperial and colonial conquest (Tezcan, 30). These transitory centuries, often associated prematurely with Ottoman decline, saw rather a stagnation of the rapid territorial and financial growth enjoyed previously- particularly in comparison to the now actively imperial European states, several of whom spent the better part 
of the next 300 years raping and pillaging their way through nearly every other continent on the planet.

The first indicator of the coming recess was the cessation of territorial expansion following Selim I's conquest of the Fatimid domains which included Egypt, the Hejaz, and albilad a-Sham. In addition to being able to orchestrate a claim to the title of Caliph- if only in name and not lineage - through the capture of Cairo the Empire enjoyed a period of relative financial comfort despite the increase in Portuguese disruptions of the spice trade in the Arabian Gulf and the Indian Ocean. This expansion of the European trade networks into routes which had once been under Ottoman control prompted another pair of crucial changes during this time as well - the influx of new world silver and the rise of mercantile economies both within and without the Ottoman domain (Tezcan, 43). During the later years of the $15^{\text {th }}$ century, due to the increased market competition and development of early capitalist economies in Western Europe, the Ottoman Empire found itself forced to transition from a primarily provisionary economy both in relation to its own citizens and in its export-to-import ration, to a mercantile one. At the same time, these changes in the Ottoman domestic markets in response to the regional ones saw the rise of a merchant class within the imperial polity, marking the first time in which a third class had existed outside of the askeri/raya' a dichotomy (Tezcan, 14). As the significance of monetary assets became more and more important for the maintenance of wealth and status, the popularity of traditional vaqfs decreased and the once charitable system was replaced with that of cash vaqfs which functioned similarly to financial trusts in the contemporary sense. While labeled "for the betterment of humanity", this practice gained prevalence as a means through which to secure fortune for one's children as the economy continued to stagnate. Where large 
sums of gold had once been poured into the spaces, buildings, and complexes for public use, these funds now went into the hands of privatized trusts (Tezcan, 23).

In addition to this economic restructuring, the Sultans - beginning with Suleyman began to develop an increased reliance on slave soldiers, bureaucrats, and technocrats taken from non-Muslim through the devshirme. This increased influx of non-Muslims within the upper echelons of the administration led to growing discontent within the religious jurors and other members of the askeri who felt themselves increasingly marginalized within the workings of the state. Combined with several failed military campaigns in the $17^{\text {th }}$ century resulting in the loss of territory and prestige, these conditions led to considerable unrest within the ranks. Similarly, timar-holdings began becoming hereditary during this time as well as due to the relative cessation of territorial expansion to produce new land for distribution; thus the state was no longer able to live up to the promise of upward mobility which had garnered it strong provincial support in the centuries prior (Tezcan, 193).

Though the empire busied itself with attempting to integrate into the European political and economic sphere, whose power was quickly crystalizing, unrest continued to grow at home. Abuses of power among the cosmopolitan merchant class grew rampant in emerging industries not yet successfully regulated and in eastern Anatolia, wherein the majority was not able to join the janissary police forces, nor guaranteed any protection from abuses of power at the hands of now embedded land-owning families. Along with a series of wildly unpopular wars in Persia and in the Balkans against the papacy, the Hapsburgs, and the Venetians, all taking place in the early $18^{\text {th }}$ century and financed through the levying of extraordinarily high "campaign" taxes, these conditions led to a series of all out revolts across the Anatolian peninsula (Celik, 29). 
These transformations and their discontents were located, by nature of their occurrence within the $17^{\text {th }}$ and $18^{\text {th }}$ centuries, during the period of time in which the world system of 'western' hegemony solidified (Wallerstein, 8). Far from eternal and far from unchallenged in recent years, this system of political, social, economic, and ideological power was born into existence to both justify and facilitate the practices which allowed Europe and later, the United States to become the determining and determinant locus of global power. The Ottoman Empire, already on the geographical periphery of Europe, became increasingly relegated to the status of Orientalized 'Other' in prevailing discourse of the continent. This is not to say that conflicts between European powers and the Ottoman Empire were unheard of before this time - Ottoman military history is littered with trade wars, espionage, and frequent campaigns in central Europe and against both central and western European powers, not to mention the crusades waged by the Papacy during the empire's lifetime; rather, the discourse of orientalism in conjuncture with enlightenment rationalism and the rise of social Darwinism saw social, cultural, political, and economic difference as indications of "oriental" societies and their inhabitants as belonging to an inferior subset of the species at large. Within this context, the Ottoman's slowness to industrialize by virtue of its need to first transition to an economic system more closely resembling European, mercantile capitalism was not seen as such; it was taken instead as evidence of the Empire being an inherently inferior civilization.

In a bid for continued relevance, the Ottomans sent their first ambassador to Paris in 1720. In addition to general diplomacy, the mission of Mustafa Reshid Pasha - the man who would later become Grand Visir and be considered the father of the Tanzimat reforms- was to take notes on French civilization and its new economic and material technologies as he felt they could be applied to the Ottoman Empire upon his return. Likewise, in order to access personal 
and familial upward mobility, it became increasingly common during the $18^{\text {th }}$ century for the youth of the Ottoman elite to attend French and British universities. The return home of these generations of students following their education brought Western European styles of personal and material aesthetic, technologies of self, state, and industry, and philosophical discourse. One such example of this was the construction of a number of palaces by French architects invited to the city by Sultan Mahmud I. The aesthetic language of French style survived, going on to be a primary influence in the development of "Ottoman Baroque", the palaces were destroyed completely in the revolt of 1730 (Celik, 29). Not yet subject to the pressure to "westernize", which was a hallmark of the $19^{\text {th }}$ century, the position of these changes was hotly contested within Ottoman urban space - the tension over which resulted in a $19^{\text {th }}$ century with nearly as much focus on material change as social change in the face of an expanding European imperial influence.

\section{Becoming-Oriental, Becoming-Peripheral: Istanbul at the End of Empire}

In her watershed work, The Remaking of Istanbul, Zeynep Celik states that Istanbul's development within the $19^{\text {th }}$ century reflects many of the social and political of the changes going on across the empire at the time. Though no similar work has tackled the $20^{\text {th }}$ century in the same way, this thesis will, from this point forward, attempt to examine Istanbul's development within the context of this socio-spatial dialectic as it manifested the discursive treatment of the city throughout the republic period into the present. Working within the theoretical framework established in the first half of this thesis, the presentation of this section of case of Istanbul's (re)development will focus on the role played by the external pressure of 
ascending European imperial power on the material and political developments of the city during the Ottoman Empire's final years. As indicated in the title, the primary institutional and narrative influences on these trajectories will be the interdependent relationship of the discourse of orientalism and the relegation of the Ottoman Empire as a whole from the position of Imperial center in its own right to belonging to the cultural, political, and economic periphery of a quickly materializing state of European global hegemony - in this case centered on Paris, France.

As Said describes the phenomena, Orientalism is primarily an epistemic relationship between states located in the "West" and the "East". In function, it is implicit in the production of both of these categories and in the reification of difference between them as a justification of Western superiority and, subsequently, Western political, cultural, intellectual, and economic domination (Said, 43). Said posits that the binary between east and west is entirely imaginary; however, rather than being reified through popular engagement with literature as the case was with European national identities, Orientalism's textual base lies largely in the production of knowledge by the western academic elite which idealizes western forms and functions of social functioning and social systems development by comparing negatively with a "backwards" and “ignorant" other (Said, 59). This knowledge production was then used to rhetorically shape and empirically justify the exploitative policies behind the formation of colonial empires.

Though the Anatolian peninsula was never colonized by European powers, Orientalism and political and economic peripheralization of the Ottoman state had a profound effect on both the state as a whole and, in particular, its capitol city. Most significantly, the systemic and epistemic transformations of the $19^{\text {th }}$ century ushered in a period of reform which laid the 
groundwork for the dissolution of the Empire and abolition of the sultanate in 1923. While their efforts to create a functional constitutional government during this time period were largely futile, reforms of the municipal organization and administration of Istanbul facilitated the extensive city-building and public works programs of which the city was in dire need. The Tanzimat Charter of 1838 formally introduced the language and philosophical constructs of Western Modernism to the Empire in order to accommodate participation in and of the international commercial bureaucracy in the economic control of and by the Ottoman administration (Celik, 33). Though not fully articulated until its Kemalist iteration, this represented the moment at which the theoretical and material conflation of "modern-ness" and "western-ness" formally entered Ottoman policy and law; as such, the policies put in place for the sake of modernizing were unarguable and explicitly intended to "westernize" the nation and its government as the two were considered akin (Eisenstadt, 15).

In order to unpack this sentiment - as unnecessarily convoluted as the power relations it attempts to describe - it should be noted that on the basis of bourgeoisie participation in the French Revolutionary discourses of "civil liberties" and "the rights of man", western European nations with clear economic dominance by virtue of their colonial enterprises were able to subsume the moral high-ground via the sociolinguistic constructs bearing the liberal-humanist ethic. Moreover, failure to conform to these parameters of this language (as the "universal rights of man" were then and continue to be a complete farce under the conditions of imperial capitalism which guarantee these concrete privileges for an overwhelming minority of the actual human population) put any given geopolitical peripheral to the European metropolitan center at risk of colonization. As such, Westernization was not an impulse but an imperative within the context of the Orientalized state apparatus and sociopolitical body, constructed and reified from 
both without and within the Ottoman polity as the traditions and institutions of Ottoman society under which progress, power, and prosperity had stagnated in the previous two centuries were deemed inferior to those of the newly constructed West. Though westernizing efforts existed prior to this time in the fields of education, technology, and industry, the Tanzimat charter imported intellectual and social systems resulting in a period of intense social change (Celik, 47). Moreover, while the Tanzimat era technically ended in 1876 with the establishment of the first constitution and the formal shift to parliamentary monarchy, the legacy of these reforms and their influence on Turkish political thought during the next century cannot be understated.

Similar to other major cities the world over, $19^{\text {th }}$ century Istanbul saw massive population expansion; however, where urban centers across Europe swelled in size due to rural-to-urban migration under economic conditions of the Industrial Revolution, the influx of people to Istanbul came primarily for sources external to its immediate political boundaries- on one hand Muslim refugees escaping violence and political unrest in Russia and eastern Europe, and on the other European investors and tradesmen seeking profit. Districts like Galata, which had already been primarily inhabited by foreigners or non-muslim Ottomans saw particular spikes in population and physical growth due to this demographic change. This population growth translated into a dramatic expansion of the physical boundaries of the city in Uskudar and Pera, including the development of what are now the prominent residential and commercial boroughs between Taksim, Sisli, and Besiktas (Celik, 38).

Fitting in with the moral impetus to modernize, the first half of the $19^{\text {th }}$ century saw a period of intense industrialization nation-wide. Within Istanbul itself, this was relegated to a ring of factory growth outside of the Theodosian Walls, as well as the construction of new ship yards and other industrial sites along the waterways (Celik, 35). Along with the machinery necessary to 
run these sites, craftsmen, foremen, and specialized laborers were imported from Europe, thus creating an economy entirely dependent on those of Western Europe. As the empire remained unable to compete with the rapid industrial development of Western nations, it became increasingly dependent on the importation of western goods and products. Already in debt, this dependency further exacerbated the Empire's financial woes - what little good did come from these changes was disproportionally located within urban spaces, especially that of Istanbul (Celik, 36). The modernization of Istanbul, considered now in full, was designated a design project with the express goal of creating a capital comparable in "organization and luxury" to those of Europe.

The Tanzimat Charter, in importing western philosophies of law and governance, both centralized and expanded the powers of the government in order to create a system capable of social control fitting the western model; however, in conjuncture with the prevailing attitude within the increasingly western or westernized Ottoman elites that indigenous cultural norms were not only 'regressive' but entirely antithetical to the ideals of progress, many of the structural changes put in place were done so in blatant disregard of the interests and values of the majority of the population. As this was reflected in the transformation of Istanbul itself, the relatively loose system of municipal administration under the kadis was replaced with a centralized hierarchy of civil servants working within state ministries. The mission of the new system of municipal administration created during and following the Tanzimat reforms, headed first by the Ministry of Public Works (est. 1838) and, following a series of set-backs and disappointments, the Commission for the Order of the City (est. 1855), was first and foremost to begin regulating and routinizing the administrative process through the formal codification of legal and administrative procedure (Celik, 43). 
According to Celik's research, the documents establishing the commission "argued that the capital cities of all leading countries were built to perfection, whereas Istanbul still badly needed embellishment, regularization, road enlargement, street lighting, and improvement of building method". Moreover, these documents stated that “...positive results could only be obtained through rules and regulations", stating that the commission itself should be composed of individuals from the foreign families residing in the city familiar with European methods (Celik, 51). This language of regulation, codification, and centralization - further echoing French liberalism in its self-congratulatory justification as being for the needs of the "greater good"became manifest in the structural changes which took place throughout the city, particularly in the concentration of their positive effects in districts primarily populated by the wealthy and western - namely those of Galata and Pera. These agencies sought to facilitate urban reform to meet the "modern" standards of European capital cities and of the city's quickly expanding population of European expatriates alike; however, due to the unfavorable economic conditions of the time and the undertrained and underdeveloped workforce, the efforts of these attempts at reform fell woefully short (Celik, 50).

In order to facilitate the structural change which the city so desperately needed in order to meet the now-European standard of modernity, a master plan for urban (re)formation was commissioned by Sultan Mahmut II in 1839. Though no copy of the master schematic has yet materialized, it appears in official documentation that the city-wide (re)development project was guided by German-born, French-educated architect Helmuth Von Moltke. Undertaken in direct imitation of Paris, Von Moltke's plan appears to have emphasized above-all-else conceptual and organizational centralization as a means of facilitating travel, communication, fire prevention, and law enforcement (Celik, 49). 
It should be noted that, though seemingly inconsequential and articulated in the same line as other motivations for change with more overtly ideological underpinnings, "fire-prevention" was a key concern to the actual wellbeing of Istanbul's population during this time. By nature of its geographical location, the density of Istanbul's population, and the use of timber as the primary vernacular building materials in residential neighborhoods, large fires swept Istanbul frequently. Though not unique to the $19^{\text {th }}$ century, the number of major fires recorded within Istanbul more than doubled between the years of 1853 and 1906 due to the exponential increase in population and, subsequently, the proliferation of cheap, timber-based houses and apartment complexes. In that the fires which so plagued the city would and did destroy entire swaths of the urban fabric at once, the aftermath of which provided ample excuse for major reform of the city's urban fabric, the large-scale structural damage allowed the new municipal administration to put into operation uniform and unilateral principles of design which were popular within the European academy at the time (Celik, 52). This focus on unity - both in design and in the conceptualization of Istanbul's urban body - is readily visible in Von Moltke's "scientific approach" to the principles of urban planning, central to which was the pleasure of the western eye (Celik, 49).

The changes implemented under this master plan were legally structured by six major regulatory measures passed between 1848 and 1882: the 1848 Building Regulation Act, the 1858 Regulation on Streets, the 1863 Street and Building Regulation, the 1875 Regulation on Construction Methods, the 1877 Istanbul Municipal, and the 1882 Building Law (Celik, 58). The sum of these acts resulted in a considerable expansion of the legal minimum street width across road-types, the all-but-eradication of timber construction - with remaining timber neighborhoods and new timber constructions relegated to spaces physically separated from new developments 
by dividing walls and tax incentives provided for the construction of new structures out of stone, brick, and concrete - and imposition of limits on building height as proportional to street width.

Beginning first with the opportunistic restructuring of the street system in the Istanbul Peninsula following the Aksaray fire of 1856, at the level of policy, this transformation was achieved through the reformation of expropriation laws, as allowed through the aforementioned regulatory acts, which stipulated that all new building projects must first be evaluated for contribution or threat to the "public good" (Celik, 51). Via the same appeal to "public good", citizens lost the right to contest state expropriation of private property. Though citizens whose property was seized were legally entitled to compensation or resettlement, these consolatory measures were almost less-than-equal to the value of the property seized. In combination with the positioning of this policy change in flagrant opposition to the concern for private property rights demonstrated throughout Hanafi jurisprudence, these measures - already wildly inconsiderate of the conditions inhabited by the urban poor and working classes- were met with considerable anger.

Through the seizure of private property in the affected areas, this period saw the widening and straightening of extant major roads in order to form clear "arteries" within the city's dense fabric. The significance of this new road system was further accentuated through clearing of space around major junctions in order to allow for the embellishment of sites now labeled "historical" and construction of squares, parks, and Parisian-style promenades. Following the Hocapasha Fire of 1865, which decimated a section of the city stretching between AyaSofya in the east, Beyazit Mosque to the west, and clear from the Golden Horn to the Sea of Marmara from north to south, swaths of residential buildings considered detrimental to the viewshed of monumental structures were cleared completely for the sake of "[adding] further beauty to the 
existing beauty of Istanbul" (Celik, 62). Headed by the I.T.K. (Islahat-I Turuk Komisyonu, Commission for Road Improvement), the express goal of these changes was to imbue the city with a sense of monumentality emulating the European conception of historical site and space. Under the direction of the I.T.K., the spaces once contained within the kulliye complexesmadrasas, cemeteries, attached gardens and courtyards - that had until this point served as the central points of organization for Istanbul's mahalles were, in yet-another example of the utter contempt in which local values and religious sentiment were held, cleared away to make room for expanded streets as well as a variety of new, public spaces such as concrete terraces, parks, pedestrian sidewalks again in direct imitation of the Parisian model (Celik, 63).

Following the Pera Fire of 1870, a similarly financially unrealistic and locally unpopular project was undertaken in the district in order to facilitate its "orderly growth"; however, where projects such as this had failed almost entirely in other neighborhoods due to the inability of the state to muster the appropriate funds, Pera was able to achieve some modicum of success. The site of a considerable concentration of the city's financial elites, a class comprised disproportionately of wealthy western immigrants and local business people who had benefited considerably from the Tanzimat policies which emphasized both increased participation in trade and the growth of internal commercial and consumer economies, the private donations collected from its citizen body were able to fund a restoration project unparalleled in efficacy and aesthetic effect elsewhere within the city (Celik, 69). Though not nearly as densely populated as the rest of the city, the fire of 1870 destroyed over 3,000 buildings in Pera, the resulting space created by which - in combination with territory expropriated from property owners situated along the extant road system - allowed for a massive widening of the streets and the construction of a Grande Rue in full Parisian style. The end result, lined with trees and coupled with a 
monumental strip complete with a façade in full neo-classical style, lighting systems and trash removal services, was the further entrenchment of Pera's attachment to the wealthy, Western and westernized elite. While the immediate reconstruction efforts were limited to the area surrounding the Grand Rue du Pera, this further concentration of the urban elite saw the establishment of several state and military schools, the creation of European-style gardens and public squares, the implementation of an extensive tram system and several of the earliest subway lines on record, the construction of a considerable number of institutional offices, private mansions, and palaces throughout the Galata peninsula during the remainder of the century (Celik, 73).

Celik posits that the proliferation of the building projects, directed as they were by European trained architects regardless of citizenship, gave Istanbul's urban landscape as a whole an aesthetic pluralism so deeply politically influenced that style could be argued to have taken on a level of political symbolism. While the highly Orientalized "Neo-Ottoman" style - which, when designed by western architects, often involved more elements of Mamluk décor than traditional Ottoman elements - and neo-Gothic saw some success in the city, the two most popular styles were by and large French-influenced Art Deco and Neo-Classical - the latter of which became the official style for official imperial construction during this period (Celik, 126$133)$.

In addition to the material construction of public space, particularly within zones such as Galata and Pera which were coded as "western", these spatial projects towards a European-styled public brought with them European-style anxieties over public presentation, morality, and performativity. As has been the case globally, the $19^{\text {th }}$ century saw women in late-Ottoman society forced into a particularly paradoxical position. While strict sex-segregation was almost 
exclusive to women of the socioeconomic elite, female members of Ottoman society across class lines were considered holders of the honor of the family unit and, as such, the presence and behavior of women was historically subject to the religious-legal constructions of proper moral conduct. During this period female members of the now well-established mercantile middle class, by nature of the global political and social intersections which they inhabited, expected to be present within the public sphere while conforming to both the European standards for their behavior and performance as well as those of their respective socio-religious background (Kandiyoti, 322).

Though far from exclusive to the youth, the position of young men in $19^{\text {th }}$ century Ottoman society was certainly as contentious as that of women - if for different reasons. While this century saw the birth of regionally, and later nationally, specific feminist movements across Ottoman domains, growing disillusionment with the Empire's failing political and military institutions saw young men ever increasingly alienated from the systems which once had held the promise of upward mobility, if a promise decreased over the past several centuries of economic stagnation. Moreover, in the case of young men coming from wealthy families, the profound cultural dislocation produced by education in and under the European philosophical discourses of the day (which saw them not only as members of a failing state, but ostensibly as less human) lent themselves an increasingly radical proclivity towards modernizing/westernizing reform (Dumont, 26).

Emerging first as the Young Ottomans, then the Committee for Union and Progress and, finally, as the Young Turks, the role of western-educated youth in driving both regime and policy change is impossible to understate. While nature and methods by which these organizations pursued their goals changed as the Empire fell further and further into decline, it 
was through the writing produced by members of these movements that can now be seen the first articulation of the national ethos which came to so define Kemalism as the political ideology of the Modern Republic of Turkey; however, the nationalism of the Young Turks was distinctly ethno-religious. This 'Turkism' was a facet of Ottoman decline (Kaya, 50). Articulated most clearly in the writing of ideologue Ziya Gokalp, the essential and eternal Turk was muslim (though distinct from the persona of the Arab muslim) and ethnically Turkic - the confluence of which was sought after within Anatolia with violent efficacy evidenced in both the GrekoTurkish population transfers and the Armenian genocide (Kaya, 55). Further echoed in the writings of young Turkish architects who, in their search for a distinctly "Turkish" style, blamed the predominance of Greek and Armenian architects during the Empire's final years for its fall from "architectural glory", this self-conscious search for a unified identity was foundational to the rhetoric, policy, actions, and architectural developments of the Kemalist Era (Celik, 150).

\section{Becoming-National, Becoming-Local: Early Republican Istanbul}

In his work Imagined Communities, Benedict Anderson posited that all communities outside of our immediate physical and social reality are the product of collective imagination the chief among them being the nation-state. The nation-state, as Anderson describes it, is a distant community of others connected through their mutual participation in the nation state as an embodied ideal. Propagated through the increased availability of literary work written in vernacular language in early modern Europe, the process of emerging national identity has been inextricably embedded within that of language and, more importantly, linguistic difference. Within the context of Anderson's worth, language became conflated with territory which was, 
and continues to be, conflated with both ethnic community, thus producing an abstracted sense of identity. As such, citizenship and, more broadly, national identity became forms and practices of self-hood (Anderson, 37). As this pertains to the Turkish situation, we must examine it within the context of the partition of the Ottoman Empire following its loss in the First World War.

Following the its military defeat in the First World War, former Ottoman territories were partitioned in what is roughly equivalent to the geopolitical landscape of the Middle East and North Africa as they stand today. During this period, Istanbul - along with several other major cities in the Anatolian Peninsula - was occupied by a contingent of allied forces; however, under the direction of Mustafa Kemal Ataturk and the Young Turks, a successful bid for independence was launched. Istanbul remained occupied until the abolition of the Sultanate in 1923; however, prior to its liberation, the decision was reached by the Kemalist government that the administrative center of the newly established Republic of Turkey would remain in Ankara (Gul, 85). A sweeping gesture towards their desire to cut all tied to perceived legacy of Ottoman failure - attributed to decadence, corruption, internal division, and backwards religiosity - of which Istanbul as a location and an artifact was particularly symbolic, the early years of the Modern Republic of Turkey as directed from the top-down by the single-party rule of the Republican People's Party (RPP) brought with them a program of social, material, and ideological transformation not unlike those of the Tanzimat Era, save for more radical in their implementation.

Kemalist ideology, characterized primarily through its (often contradictory) commitments to republicanism, secularism, populism, nationalism, etatism, and modernism, carried the express goal of "achieving the level of contemporary civilizations" (Dumont, 26). This conception of the 
Turkish nation was formed in direct response to the decay of the Ottoman Empire. As detailed by Ibrahim Kaya in his work Social Theory and Later Modernities, Kemalism was distinct from the pan-turkic movement in a number of crucial ways

Kemalism broke with imperial ambition by declaring a Turkish nation in a certain delimited territory: Anatolia. Kemalism broke with Turkism in that the Kemalist definition of the Turkish nation was derived from not ethnic "oneness" but, in contrast, from a common history in a common territory and a belief in a common future. Nationalism meant the necessary process of bringing about a 'civilized Anatolia'. Therefore what needed to be done was to 'disembed' people in order to 're-embed' them in the form of the Turkish nation. (Kaya, 61)

Per this definition, Kemalism must be understood as a territorial ideology, which requires us to acknowledge the unavoidable link between autonomy and modernity...the self-determination of a people within a clearly defined boundary was necessary for the construction of a republic. Moreover, Kemalism, esp. according to Gokalp's teachings, criticized the Ottoman governing class as being cosmopolitan and imperialist, putting its own class interests above 'national' interests. As such, the policies, programs, and rhetorics implemented between 1923 and 1946 worked intentionally towards the realization of an ideal as decidedly social and cultural as it was economic (Dumont, 25). Given that the condition of Istanbul within the early Republican era was one of both internal and external peripheralization, this section will focus on the relationship cultivated within modern Turkey to its own past with the former imperial capital as both a site in which these changes were enacted and as something of an allegory body of the Turkish citizen as they were socially, politically, and economically reconstituted within nationalized civil society. 
Not unlike the French Jacobins during the 1800s, the RPP outlawed or removed symbols or visible signs associated with the old. Among these efforts to cleanse it of Ottomanism was the particular focus on curating a secular society. As such, the defunding of religious schools, the removal of the Mufti of Istanbul and all other members of the 'ulama removed from positons of legal or judicial power, the banning of public religious practice and dress, the establishment of a secular-state feminist movement, the reformation and westernization of the Turkish language, and the implementation of the Surname Act of 1934 which required all citizens to take formalized last names in the western sense were within the first changes implemented by the new state apparatus (Cleveland and Bunton, 181).

In their strict adherence to secularism the Kemalists looked to language as a primary indicator of identity, insisting that Turkish - as the language of the state - was to be the language of the public as well. In addition to asserting the nationalization of the public space through the mandating of nationalist performances of the public self, this emphasis on language had a significant impact on the Kurdish population specifically. Kemalism denied the existence of race or racialized identity; however, in doing so it erased racialized difference as a real aspect of social class. Where the Young Turk government was strongly influenced by race realism, the Kemalist state sought to eliminate the notion of race altogether; however, much of the educational curriculum maintained the idealized image of the Turkish nomad as the ancestor of all Turkish citizens. Unity of language and culture juxtaposed with linguistic and cultural cleansing enacted in order to absorb groups newly relegated to the position of minorities particularly that of the ethnic Kurdish population in eastern Anatolia. Already spatially distal to the major centers of commerce and production, when finally addressed by the Kemalist elites they were quite literally told that Kurdish-ness was a "false narrative" of identity and that to 
participate in it was akin to undermining Turkish-ness, which was itself "glorious" to claim (Dumont, 28). In relegating Kurdish identities legally to non-existence, the regime made the act of even speaking Kurdish in public punishable by law - a policy which not only affirmed the public as the dominion of the nation, but overtly equated public Other-ness with treason.

In moving the central government to Ankara, the position of the RPP towards Istanbul was that of the city, with its burden of symbolic value, as the past manifest- corrupted and corrupting - from whose clutches the nation-state intended to escape at all costs. Cultural and material resources once allocated to Istanbul were funneled into farm subsidies and provincial development in accordance with the Kemalist desire for agrarian populism, as well as into Ankara in order to support the construction of an entirely new, purpose-built capital city in the style of post-war European Modernism befitting the Kemalist regime's modernizing ambition. As detailed in Modernism and Nation Building

The architectural culture of the early Turkish republic amply illustrates how high modernism as an ideology appealed particularily to 'planners, engineers, scientists, and technitions' who 'wanted to use state power to bring about huge, utopian changes to people's work habits, living patters, moral conduct, and worldview.' Modern Architecture was imported as both a visible symbol and an effective instrument of this radical program to create a thoroughly westernized, modern, and secular new nation dissociated from the country's own Ottoman and Islamic past. In this respect, architecture in early republican Turkey can be looked as a literally 'concrete' manifestation of the high modernist vision (Bozdogan, 6) 
This is to say that, while constrained by the economic conditions of the time, Kemalist architects placed special emphasis on "rationalism and functionalism" -as opposed to the aesthetic implications of international style- in their efforts to import the scientist, positivist, and progressivist characteristic of modernity. As such, this period was one of marked neglect of the former Ottoman capital as it lost all of its previously enjoyed political privilege while simultaneously experiencing significant economic decline and effective depopulation (Gul, 72). With the merits of city life being discouraged nationwide by the RPP in order to stem migration from rural areas, migration to Istanbul - considered at this point a stronghold of loyalists to the old regime - was particularly disincentivized. Furthermore, the non-Muslim merchant class and new bourgeoisie which had flourished during the $19^{\text {th }}$ century left the city in droves. This flight of the former elite was coupled with the termination of the employment of tens of thousands of former Ottoman bureaucrats and technocrats living therein, as well as the redirection of nearly all funding for public resources to Ankara (Gul, 86).

While private development continued in the residential neighborhoods of Galata and Pera due to the continued investment of private landowners, the most significant changes to the city at the level of structure were largely symbolic. Of these, the most significant were the transformation of Ottoman historical sites and mosques - including the Aya Sofya - to museums and the renaming of streets once called after sultans, members of the old regime, or bearing names in western languages to reflect the achievements of Kemalist figures and ideology - one such example of which being the renaming of La Grande Rue du Pera, which stretched from Galata to Taksim, to Istaklal Caddesi - meaning liberation or independence (Gul, 93). Parallel to these changes was the formal and final destruction of the power of the Imam at the local level of 
neighborhood administration and governance. Mirroring the Tanzimat reforms, Istanbul was constituted a municipality to be governed by a grand committee and a mayor; however, these new officials could do little to stem to tide of urban decay that accompanied the early years of the Great Depression. Met with open resentment by the central government, Istanbul's economic, physical, and affective states continued to decline rapidly throughout the subsequent decades despite its continued position as the cultural and economic heart of the Republic. Though plans for its redevelopment were commissioned, the funding for implementation was quite simply lacking until the economic boom of the 1950s (Gul, 107).

Formally contracted by Ataturk as Istanbul's chief city planner in 1936, the master plan formulated by French architect and planner Henri Prost formed the backbone of the changes which would be later implemented under Prime Minister Adnan Menderes. In continuum with the express goals of the Moltke plan, Prost's plan focused on the improvement and expansion of roads, the improvement of communication networks and infrastructure across the city, the expansion of existing public spaces and the creation of new ones, and the regularization of urban fabric for the sake of fire prevention; however unlike the Moltke plan, Prost's opted to approach its development by dividing it between residential, commercial, recreational, and industrial zones (Gul, 100-101).

Though complete documentation of Prost's plan does not appear to have been preserved, it appears that one of the most significant aspects was that of automobile accessibility and vehicular travel. Consistent with the planning theories of the time, Prost centered the issues of modernization and conservation; however, this effort to conserve saw only the monumental as significant, to which the vernacular was antithetical. The vision proposed for the Istanbul peninsula would have required the carving up of the extant urban form in order to implement an 
extensive new road system capable of managing multilane traffic - the result of which would not only have almost entirely eradicated the extant urban fabric and isolated structures deemed to be of historical significance only to have them choked by highways (Gul, 119). Another aspect of particular focus herein was the drastic reformation of the areas around the Golden Horn as well as that of Galata and Pera at large; Prost's plan included the creation of industrial zones along the Golden Horn, wholesale reconstruction of the road system, the creation of parks, promenades, and stadiums throughout area, and the complete expropriation, destruction, and reconstruction of everything between the Golden Horn and Taksim (Gul, 112).

Prost's plan was accepted by the municipal government in 1938; however, due as much to unfavorable economic conditions as to technical deficiencies on behalf of the municipality and lack of topographical and statistical data on behalf of Prost himself, much of the sweeping changes which this plan demanded were wildly unfeasible and, therefore, only marginally implemented (Gul, 111). Furthermore, the drastic changes for which the plan called required a legal framework to which the central government was largely unwilling to lend support. The few aspects of the plan implemented were largely in fragments. Ataturk Boulevard was not extended to Ataturk Bridge, though it was widened by several lanes; The dense cluster of houses and apartment buildings around the Eminonu entrance to the Galata Bridge was cleared, thus opening the area up to increased foot traffic; Taksim, if not entirely cleared, was reorganized to be more friendly to cars and pedestrians with changes including the construction of Inonu Promenade and the destruction of both the Pangalti Armenian Cemetery and the Halil Pasha Artillery Barracks in order to create space for Taksim Gezi Park (Gul, 116).

Though under the leadership of Ataturk's successor, Ismet Inonu, Turkey did not directly participate in the second World War; however it did suffer considerably from wartime shortages 
of goods imported from Europe, from the diversion of what limited funding the national government had towards defense, and from the general falter of the global economic system during the early 1940s (Gul, 120). These changes were felt most pointedly in provincial areas, triggering what became over the next several decades a tidal wave of rural-to-urban migration within Anatolia (Gul, 122). The combined frustrations over hyperinflation, poor bureaucratic control over profit margins, and crumbling infrastructure led to a similar erosion of the RPP's urban support base as well - the result of which crystalized in the form of political opposition to Inonu's RPP in the form of the Democrat Party (DP). The formation of the DP saw Kemalism transformed from the unitary ideology of the state to one of many dynamic and competing imaginations of the Turkish nation, the Turkish citizen, and the Turkish future.

Established in 1946, the DP's platform of economic liberalization did not pose a major threat to the RPP's hold over the nation in its first election; however, with the massive US investments in Turkey under the Marshall Plan and the Truman Doctrine in the late 1940s, the DP was able to bolster considerable support as the RPP proved less and less capable of managing the post-war economic situation (Pope and Pope, 123). Not only did the mechanization of agricultural production and improvement of rural road systems accelerate the collapse of the 'peasantist utopia' of Kemalist rhetoric, but the flaws in Republican development schemes were thrown into sharp relief as the nation's urban centers swelled in size (Gul, 123). These political and economic changes were further coupled with a relaxation of some of the early republican restrictions on public religiosity, allowed greater freedom of the press, and extended a level of autonomy to universities and professional associations over their own internal affairs. The political result of these shifts in policy across the board was a shocking upset in the 1950 municipal and provincial elections which saw the DP seize the overwhelming majority of the 
National Assembly, as well as the office of the Presidency (Gul, 126). With the ousting of the RPP, President Bayar and Prime Minister Adnan Menderes ushered in an era of unprecedented economic and social liberalism; moreover, during Menderes' many terms in office, the redevelopment of Istanbul became a matter of national priority as the city reemerged as the most influential in the nation.

\section{Becoming-Open, Becoming-Conflicted: Istanbul at the Crossroads}

While Istanbul had remained a site of cultural and industrial prominence throughout the early republican era, the post-war economic boom of the 1950s saw the city recapture a position of political significance as Turkey as a whole was realigned as a geopolitical bridge between U.S. global anti-communist interests, Eastern bloc powers in Central Asia, and the MENA region at large. This period of Istanbul's narrative and material progression can be primarily characterized as one of rapid and chaotic destabilization. Between explosive population growth, a return to political significance - if within tenuous internal and external climates, and the definitive fracture of the social and political unity which was so prized by the Kemalist regime, the city seen here is one being pulled, pushed, and propelled in a multitude of increasingly competing directions. The following section, which is itself decidedly more narrative in its approach than the others in this work, will seek to throw into light the conditions which bridged the seemingly insurmountable ideological gap between the unitarily nationalist isolationism of the Kemalist modernity and the (post)modern.

Contrary to the rhetoric of liberalization upon which the DP was placed into power, its approach to the redevelopment of Istanbul was largely centralized. Due as much to shrinking 
margins of growth and the decline in foreign aid towards the middle of the decade as to the jump from a population of approximately 285, 000 in 1950 to somewhere near 1 million in 1955, many of the social policies implemented earlier during their tenure in office were reversed (Gul, 146). This mid-century change in social policy not only severed the DP's allegiance with the city's middle class intelligencia; but, combined with its sponsorship of the anti-Greek demonstrations of September 1955 and, subsequently, deadly and destructive riots targeting Beyoglu's Greek community, this period was marked by a sense of loss directed at the cosmopolitan character upon which Istanbul had prided itself for so long (Oncu, 95).

As neglect was blamed for the failure of earlier renewal projects, the DP, under Menderes oversight, embraced Istanbul's Ottoman past as a means to symbolically differentiate the party from its predecessors and embrace the redevelopment of the city itself with particular interest, investment, and involvement (Gul, 127). Due largely to poor documentation and record keeping, any material evidence of a master plan has yet to surface - in fact, the question of whether or not the development projects of the city were planned or entirely ad hoc was one of particular importance in Menderes' trial following the 1960 coup (after which he was summarily executed for violation of the constitution, embezzlement and illegal seizure of property, among other charges) - however, correspondences between Menderes himself and his officials point to some sort of central plan or planning ideal (Gul, 140). Though we do not have the documents themselves, the pattern which demolitions and reconstructions followed hints that the key points of this plan likely bore marked similarity to those of the Prost plan, albeit less structurally drastic in nature.

Prost himself was removed from office by the DP administration in 1950 for his failure to bring the desired reform to Istanbul during the decade prior; however, the establishment during 
this decade of the legislative and legal frameworks for which Prost had initially advocated constitute one of the most significant contributions of the DP administration to Istanbul's social and structural reformation since (Gul, 136). Officially launched in 1956 under the direction of the Permanent Commission for Istanbul's Master Plan (also known as the Board of Advisors, Musavirler Heyeti), the Redevelopment Programme was characterized by two provisions in particular: reformation of the road system for the sake of creating both pedestrian boulevards and a highway system and unconditional support for demolition. In order to facilitate both the clearing of the urban fabric and the desired road-system reform, the policy changes here focused primarily on relaxing restrictions on the classification and expropriation of land (Gul, 145).

Between 1950 and 1956, the DP administration spent over 13 times more on compensating expropriations within Istanbul than the RPP had at any point during its 27 years of rule; however, by 1956 the population growth had reached such a rapid rate that funding expropriation at the scale necessary to implement the desired projects was no longer feasible. The solution to this issue came in the form of the Voluntary Renunciation Formula which allowed for agreements to be made between owners of private property and the municipal administration to forgo up-front compensation (Gul, 143). Due in large part to this policy, estimations of the number of buildings demolished by 1960 range from the conservative figure of 5,540 presented within official documents to a scholarly approximation of about 7,290 to newsstand speculations close to 10,000 (Gul, 144). The lax nature of the Voluntary Renunciation Formula allowed for considerable corruption, both on behalf of the municipality - members of whose government admitted to using coercive tactics in order to scare residents into vacating property without proper compensation in addition to often failing to follow through on promised payments at all - and on the behalf of individuals with political clout interested in seizing land 
for private, personal use or as a means to launder money. Attempts to stand in the way of this perceived progress within and without the administration were met with open hostility (Gul, 144).

While few buildings of monumental significance were constructed during this period, these policies allowed of the realization of Prost's plans concerning the opening of space around extant historical and monumental structures now designated "tourist destinations", the expansion, regularization, and widening of roads to facilitate vehicular travel, and the construction of new residential areas to accommodate the new, business-oriented middle class. Dominated throughout by post-war international style, these residential areas included garden suburbs, villas, and gated communities near the emerging business sectors along the Bosporus such as Besiktas and Levant (Bartu, 35). These constructions, reflective of the growing class division within the city, marked the beginning of a systemic division of Istanbul's urban ecology between the increasingly polarized opposites of legal and illegal - the mapping of difference upon the latter of which became a dominant trend within the sociocultural discourse of the city for the remainder of the $20^{\text {th }}$ century (Keyder, 143).

As was the case with Prost, official speeches constituted the vernacular structures of gecekondu (communities of shanty-houses built by residents for personal use on public, vacant, or peripheral land) which had proliferated at an unparalleled rate during the population inflation of the late 1940s and early 1950s as the opposite of the historical; however, the language of this period in reference to vernacular development also worked to equate gecekondu with the ugly, the primitive, and the backwards. As such, gecekondu were addressed not just as a threat to the physical security of Istanbul, but its social life at large - the elimination of which under this program of urban redevelopment was championed by Menderes as a demonstration of effective 
administration in the face of economic downturn. From these rhetorical devices, in conjuncture with the wildly discriminatory practices of development which they sought to justify, emerged the gradual criminalization of the already socially marginalized and spatially peripheralized lower classes (Keyder, 149).

Following the 1960 military coup, the Democratic Party was formally banned from politics. Its former constituents and members were split between the remnants of the RPP, whose economic policy had turned towards economic liberalism under the influence of Inonu and his successor, Ecevit, and a number of new parties which arose to take the DP's place, the most important of which being Suleyman Dimeral's center-right Justice Party (Pope and Pope, 9). This state-level political fragmentation was reflected in the rise of armed interactions between the increasingly entrenched, factional, political organizations within Istanbul itself. Loosely divided between leftist, secular-rightist, and Islamist cohorts, this trend was born out of the political and social liberalization of the early 1950s and, despite increasingly violent repression tactics on behalf of the state, continued with increasing intensity until the 1980 coup (Neyzi, 423). Due directly to the organizational autonomy granted them during post-WWII liberalization, university campuses, labor unions, and community organizations in gecekondu neighborhoods as the particular habitus of these factional groups, themselves formed primarily of disillusioned youth facing an increasingly uncertain economic future. Not unlike the positioning of youth in the Kemalist period as vanguard of the nation, students across political lines alike saw themselves as fighting for Turkey's future; however, following the military coup of 1960, these student and youth organizations shifted away from isolated campus and neighborhood demonstrations towards armed clashes (Neyzi, 425). 
Architecturally, the 1960s saw no new master plan for the redevelopment of the city and, as such, Istanbul continued to face many of the same issues to an ever increasing magnitude. Rapid economic and demographic urbanization led to increasingly chaotic patterns of growth and expansion due to deteriorating physical infrastructure, declining resources on behalf of the central government, and private sector growth which far outpaced the government's mechanisms of control and regulation. Istanbul's exponential population growth meant that the gecekondu remained the most in-demand form of housing along the urban periphery throughout the 1960s and 1970 s - meanwhile, by $197344 \%$ of all private manufacturing and $51 \%$ of all employment in the private sector nationwide were located within Istanbul (Keyder, 12). Despite the military's attempt to reassert control with the 1971 coup by memorandum, these trends continued to accelerate throughout the 1970s as Istanbul and Turkey as a whole were thrown into a period of intense instability.

Beginning promptly in 1971 and continuing until the crackdowns imposed after the 1980 coup, organizations still largely comprised of students on both the left and the right carried out bank robberies, took and ransomed prominent hostages, staged political assassinations, and orchestrated targeted bombings. Due to demographic and ideological similarities, right-wing groups, particularly secular neo-fascist organizations such as the Grey Wolves, received favorable treatment and, in multiple documented cases, direct assistance from city police forces (Pope and Pope, 316). While by no means entirely innocent in their own right, left-wing, syndicalist, and Marxist-Leninist groups became the targets of increasingly heavy-handed state repression, with mass arrests, state-sanctioned torture, assassinations and public executions occurring frequently, all the while being literally out-gunned and figuratively out maneuvered by rightist groups with increasingly strong ties to both municipal and national political agents - 
where rightist students colluded with state officials, the bodies of leftist affiliated students were hung from gallows and splayed across state newspapers alike (Pope and Pope, 133). Moreover, periodic martial law throughout eastern Anatolia coupled with rightist violence against ethnic and religious minorities created conditions in which massacres abounded.

Though temporarily halted by the 1980 military coup, these forces of political, economic, spatial, and narrative fragmentation whose seeds were planted in the city's soil have grown since into the impenetrable tangle of the its condition within the emerging neoliberal, global, and (post)modern contemporary. While conflicting and conflicted during the decades just described, Istanbul has since grown so rapidly in terms of physical expanse and population size that the scale at which the city operates is hardly comparable; moreover, in terms of positionality, it has emerged from this state to one of the world's foremost cosmopolitan centers. The following and final section of this work will analyze the city as it enters the contemporary as one of embodying a state of perpetual motion.

\section{Becoming-Global, Becoming-Fractured: Contemporary Istanbul Emerging}

In 2012, the University of Washington's Runstand Center for Real Estate Research published their annual study on contemporary urbanisms using Istanbul as a case through which to analyze sustainable development within the mega-city complex. Titling their final report "The Conflicted City", the authors portrayed Istanbul as sitting "at the crossroads" of several developmental trends which, if not addressed, would spell increased instability in years to come. It is no coincidence that the very issues highlighted by their work - namely conflicting patterns of residential development towards an increasingly disrupted urban fabric, growing concern over 
environmental sustainability, and the coinciding youth boom and decreased social mobility were the very same which were articulated nation-wide through the now-famous Taksim-Gezi Park protests of 2013. Far from occurring within the $21^{\text {st }}$ century alone, the issues both identified by this piece and at the core of the Gezi Park movement (as well as the impetus towards the massive state violence against protesters) are the result of trends which were born out of the social and legal transformations implemented by the state following the 1980 military coup. Moreover, in that the emergence of Istanbul's contemporary situation has so shaped by this acceleration towards fragmentation, it is crucial that relationship between these socio-spatial elements of urban (re)development be put in conversation with the cultural and political trends towards the synthesis of Turkish and Islamist identities and the militarization of everyday life which so characterized city's (post)modern condition. Coinciding with and in many ways embodying the effects of (neo)liberal globalization within the Republic, the forces at work during Istanbul's (post)modern present have produced within the cosmopolis particular ecologies of violence as it has become ever-more fragmented.

Though far from unprecedented, the military coup of 1980 constituted a distinct shift in Turkish political development, economic policy, and society at large. Following over a year of preparatory planning, the armed forces - led by general Kenan Evren - swept Istanbul and Ankara, deposed the former administration in full, instituted an interim military government and instituted by 1982 a new constitution whose express goal was the defensibility and indivisibility of the nation via the recentralization of the military within the administrative apparatus and the expansion of the executive powers of the standing president (Pope and Pope, 184). These security provisions were coupled with the absorption of members of many of the prominent rightist organizations into state political institutions due to their nationalist orientation; 
meanwhile, while far right extremist groups, such as the Grey Wolves, not only remained were still active on the fringe, but received notably privileged treatment from the state as internal political actors (Pope and Pope, 130).

This turn by the state towards the right was coupled with the significant constitutional reduction of individual rights and freedoms for the sake of national security under the rhetoric of counter-terrorism. While accomplished within the bounds of liberal-humanist linguistic norms set by European imperial during the $18^{\text {th }}$ and $19^{\text {th }}$ centuries that have remained a measure by which state legitimacy is judged globally, the security measures facilitated by this constitution worked to reassert the state monopoly on violence at the national level. As such, the policies implemented during this period opened the door to the broad-scale use of lethal force against Istanbul's civilian population by its police force, now institutionally sanctioned in its rightist tendencies and allowed nearly full autonomy so long as their actions could be justified as in the interests of national security - the result being an uneven militarization of everyday life and experience across ideological and identitarian lines in which groups at the ethnic, social, political, and economic periphery bore the brunt of this brutality (Pope and Pope, 145-146).

Though the constitution maintained that all were still technically guaranteed the right to life, the right to self-defense was suspended when in situations in which it could endanger a members of the police or military forces. As a result, the murders of entire families within their own homes during police raids could be explained away by labeling the victims in question "suspected terrorists". Likewise, though freedom of association was technically guaranteed, between 1980 and 1984 over 178,550 people -of whom two-thirds were leftists and one-sixth were Kurdish- were detained in some cases for periods of time lasting upwards of several years for supposed affiliation with known "terrorist" groups (Pope and Pope, 149). This rise in- and 
sanction of violence by the state as mediated along lines of identity coincided with the resurgence of American (neo)imperialism within the Middle East in the forms of the Gulf War and the destabilization of Iraq to Turkey's immediate southeast.

By virtue of its anxieties over territorial stability at the national level, treatment of those viewed as internally other and or otherwise implicit in the existence of internal instability took a turn for the worst during the 1980s and has since accelerated in effect and reach. Particularly troubling to Turkey's international reputation was the notable restriction of the press beginning in the years after the 1980 coup. While freedom of speech and press were still technically protected, the constitution specifically stipulated that "no protection shall be afforded to thoughts and opinions contrary to Turkish national interests". As a result, publications which broached topics too critically were at risk for immediate closure, and the arrest, detention, murder, and public assassination of journalists became terrifyingly commonplace (Pope and Pope, 145-146).

Coupled with this turn towards a more centralized and militarized state apparatus, Turkey's economic restructuring took a turn towards the decidedly (neo)liberal. This was due largely to the policies created and implemented at the hands of Prime Minister Turgut Ozal, head of the Motherland Party and decided proponent of economic liberalism. In combination with the changes made to the national political system following the coup, the structural-economic adjustments implemented under Ozal from his appointment until his death by poison in 1993 worked to reassert state control over civil society through economic development achieved by situating the nation more firmly within the international market. A former employee of the World Bank and counseled throughout by the IMF, Ozal reduced the state's economic control considerably in order to internationalize capital within its economic system while simultaneously incentivizing and facilitating the real estate boom which fueled the spatial growth of Istanbul 
itself (Burdett, 46). As a result of this "heterodox neoliberalism" Turkey saw the wide-scale juxtaposition of private wealth with public poverty, the emergence of an Islamist bourgeoisie faction to rival Istanbul's old, industrial core, as well as the development of distinct class cultures as ever-growing disparities in income came to be reflected in lifestyle and consumption patterns (Karatasli, 389).

With the decline of the Soviet Union throughout the 1980s, Turkey became poised to recapture regional significance and, indeed, received a tremendous influx of foreign investment, the majority of which was concentrated within Istanbul as a concerted effort was launched under Mayor Dalan to achieve the rank of Global City (Keyder, 15). Coupled with a major influx in state funding for the first time since Menderes, Istanbul saw the construction of five star hotels, high-rise office buildings, massive shopping complexes specifically intended to market luxury goods, the proliferation of fast food chains, and the construction and opening of foreign banks, primarily from the gulf. While ultimately unsuccessful in grasping the title, Ozal's Global City campaign transformed Istanbul from a metropolis to a world-class megacity complete with a high culture reputation for art, fine dining, and nightlife as well as considerable sprawl, ghettoization of the urban periphery, exorbitant corruption, a blossoming informal economy, and a special location within global black market trade (Keyder, 18).

Coupled with a spike in tourism to nearly 10 million visitors per year, Ozal's policies shifted Istanbul's economic structure away from manufacturing and towards commercial and service industries. Istanbul, reemerging as a cosmopolitan center, became the gateway through which Turkey's integration into the global system was negotiated and carried forward (Keyder, 19). Of particular importance to the city administration under this new, neoliberal framework was the curation of a manageable and commodifiable "cultural identity" particular to Istanbul as 
a marketable object, a unified (if not homogeneous) landscape, and an urban ecology palatable and welcoming to potential international consumers and multinational investors (Keyder, 20). This process as it has continued through the present is exemplified in the patterns of (re)development of the city's residential areas and in the gentrification projects of Beyoglu and Pera, as well as within the Istanbul peninsula, aimed at producing "historical districts" as tourist destinations and sites of foreign investment (Bartu, 34).

The $20^{\text {th }}$ century project of reiterating Pera and Beyoglu's European heritages saw continued investment in gentrification projects intended to curate an aesthetic and narrative nostalgia which served to both connect the areas with their legacy of French influence, as well as produce centers which would be palatable to European tourists - a consumer section of particular importance given Turkey's standing bid for entrence into the European Union. In addition to these progressions, however, came a new trend that was mirrored in the politics of the latter half of the decade and into the new millennium: Islamism. As this pertained to the city's symbolic landscape, the 1990s was the beginning of the trend towards cultivating Istanbul as an object of nostalgia within the Islamist imagination - a process which was accelerated under the AKP administration - which worked to recenter the city’s past Islamic glory (Bartu, 43).

Already complicated by the legacy of post-war sectarian violence as well as the reality of sustained state violence against the Kurdish population at large, the identity politics of (post)modern Istanbul - as well as Turkey as a whole - were particularly complicated by the articulation during this time of the "Turkish-Islamic Synthesis" within both local and national politics (Bartu, 40). Though it had existed within Turkish political discourse since the Young Turks' writings, the convergence of ethnic Turkish and religiously Muslim identities emerged as a facet of mainstream discourse on the politics of local identity until the mid-1990s with the rise 
of the Welfare Party. While undoubtably genuine at the level of the populace, the divergence between the rhetoric of Islamism and the policies enacted by Islamist parties and candidates positions this trend as curiously performative in its relationship to neoliberal development policy, if not culture.

Under the leadership of Ozal's Motherland Party and Dimeral's True Path Party, the Welfare Party emerged as a significant political force with current President Tayyip Erdogan's election to the position of Mayor of Istanbul in 1994. Running jointly on the promise of reestablishing populist safety and on a personal narrative of having been raised in "deep" or "folk" Istanbul, Erdogan was able to garner support through a claim to authenticity by capitalizing on the relationship constructed between the "local" culture and Islam by secular political figures and discourses since the Kemalist era (Navaro-Yasin, 74). Moreover, by tapping into the legitimately politically marginalized groups at Istanbul's spatial and social peripheries, Erdogan constituted the Muslim-Turk as a downtrodden class within civil society while promising the return of a functional welfare system to remedy the economic woes of the newly urbanized poor, and in doing so was able to forge a connection between Islamism and populist identities (Bora, 55). Of further significance is that, through the rhetorical catering to the Islamist imagination, Erdogan was able as mayor to bolster populist support for the acceleration of demolition projects and the continuation of (neo)liberal development policies.

While the success of the WP was nationally significant in that it formally incorporated the right-of-center Islamist factions which emerged during the Menderes years into the state apparatus, it is the relationship between Islamist rhetoric, policy, and the formerly nationalized public sphere that has captured the attention of many scholars. As Erdogan's rhetoric veered substantially towards the overtly Islamist, Istanbul's public sphere and public spaces became an 
ideological battleground over, upon, and in which the ever fragmenting imaginations of the relationships between self, space, and state control were fought as conservative social policies and attitudes were met with the development of organized social and political groups around issues of identity (Navaro-Yasin, 63). The result of these processes was not only growing conflict, but growing contradiction. Pulled in increasingly many directions, Istanbullites who saw themselves as secular and cosmopolitan felt threatened by the rise in populist politics. In contrast to the rising tide of anger from those viewing themselves as the social and economic periphery, this increased cultural (as opposed to political) polarity produced what many several prominent urbanists writing on and in the city during this time termed a trend towards "cultural schizophrenia" (Navaro-Yasin, 70). Though Navaro-Yasin pens this claim from her own perspective as that of a secular, upper-middle class academic, she points towards a very real trend in political organization and subjective identity formation.

In addition to continued violence by and against ethnic and religious minority groups, the years between 1994 and 1998 saw a notable rise in sexual harassment (as well as the formation of liberal feminist political organizations), a dramatic increase in violence against perceived queer, trans*, and gender non-conforming peoples (as well as the formation of left and liberal LGBTQ political organizations), introduced restriction on the sale of alcohol and the purchase of other illicit substances (as well as the continued proliferation of bars, clubs, and black market trade), and the entrance of cultural elements perceived to be tied to Turkey's Islamic heritage into mainstream music, fashion, media, and literature (as well as the formation of distinct subcultures across the political spectrum) (Keyder 21-25; Neyzi, 420-422). It is worth noting that the organizations and trends emerging as responses to the Turkish-Islamic synthesis drew considerable influence from those of Europe and the U.S. - indicating that, despite the rhetorical 
"turn to the east", the influence of (neo)imperial political forces within the context of globalization were still largely at play.

This state of fragmented synthesis produced by competing imaginations of ideology and identity was by no means unique to Istanbul; furthermore, this trend continued to accelerate nationwide through the dawn of the new millennium. Even after the controversial Ergenekon trials of 1996, the banning of the Welfare party following the 1997 coup, and his removal from office and subsequent imprisonment for utilizing his political platform to explicitly invoke a conception of the Turkish nation as existing tied to Islam, Erdogan was able to emerge as a figure of political relevance at the national level as the leader of the populist, Islamist Justice and Development Party (AKP) despite being formally banned from politics until 2003 (Pope and Pope, 322).

The dawn of the new millennium saw the competing political forces within the Turkish polity come to a definitive head as nation-wide frustration with the political gridlock produced by the coalition government met mounting economic anxieties over the sheer amount of debt incurred to the International Monetary Fund during the 1980s and 1990s due to reckless government spending and lack of regulation within the financial sector which ultimately culminated in a domestic financial meltdown in December of 2000 - both of which were further thrown into relief by region-wide turmoil created by the 9/11 attacks and the subsequent shift in American foreign policy towards (neo)conservative hawkishness. As such, the AKP was able to gain political momentum as an opposition party (Karatasli, 4). Winning the general elections of 2002 by a landslide - including many from those who viewed themselves as the cosmopolitan elite out of sheer protest - and taking the Presidency in 2007 under the joint leadership of party co-founder Abdullah Gul, Erdogan was appointed Prime Minister in 2003 and has held this 
position until his own presidential victory in 2014 (Karatasli, 5). As was the case with Istanbul specifically during his tenure as mayor, Erdogan's appeal to public morality and Islamist populism have been as much a hallmark of his as the disparity between his populist rhetoric and his maintenance of elite-oriented, neoliberal economic and development policies.

In addition to the legal framework established under Menderes, legal reformation concerning land use and development following the AKP's rise to power has allowed demolitions of Istanbul's vernacular landscape to continue throughout the city at an exorbitant rate through the expansion of the powers of the mayor and the municipality government as a whole (Bartu and Canden, 12). The new powers include:

(1) broadening the physical space under the control and jurisdiction of the greater municipality; (2) increasing its power and authority in development (imar), control and coordination of district municipalities; (3) making it easier for greater municipalities to establish, and/or create partnerships and collaborate with private companies; (4) defining new responsibilities of the municipality in dealing with "natural disasters"; and (5) outlining the first legal framework for "urban transformation," by giving municipalities the authority to designate, plan and implement "urban transformation" areas and projects (Bartu and Canden, 13)

Passed around the same time as these laws expanding powers of the local municipality have been a series of laws allowing instances of government intervention in order to legitimize already ongoing reconstruction projects in areas considered to hold historical significance. These laws, including Law no. 5366 (Law for the Protection of Dilapidated Historical and Cultural Real Estate Through Protection by Renewal) passed in 2005, the 2010 European Cultural Capital Law 
approved in 2007, work to override many of the regulations which had survived economic (neo)liberalization thus far (Bartu and Canden, 14-15). In addition to the continuation of the predatory expropriation practices for which Menderes was himself executed, these legal provisions allow land previously classified as public -both interior to the old quarters and in the formerly-protected forests beyond the city's perimeter - to be reclassified and sold by the city government to private developers, multinational corporations, and (as was the case with the construction of the current Presidential palace) exorbitantly wealthy individuals. The trajectory of these developments has been reflected with particular clarity in the divergent patterns of residential architecture across increasingly binary class divisions. As the residential vernacular of the gecekondu was systemically razed to the ground within the built-up core, Istanbul's periphery has seen an explosion of new slum construction.

These qualitative measure of structural integrity have, in many instances over the past decades, allowed for the specific targeting of neighborhoods populated by ethnically or religiously marginalized groups. Take, for example, the case of the neighborhood of Tarlabasi: located alongside Istaklal Caddesi, Tarlabasi has been a prime target for developers since the 1980s. A slum composed primarily of a portion of the city's Roma community which has been there for countless years, Kurdish migrants who arrived in the area during the 1920s and 30s, and (often illegal) immigrants from Africa, the majority of Tarlabasi's population do not have deeds to their homes despite having lived in them for generations. Furthermore, as part of the gentrification of Beyoglu as a district, the neighborhood was further isolated from the general public by fences put it along its border with the main road which cut off foot traffic to local businesses as well as restricted mobility for residents therein. State seizure of the land began in 2006 when, under Law 5366, 278 blocks of its historical $19^{\text {th }}$ century houses were seized without 
the consent of owners (even those with present deeds) and sold the private development company GAP Insaat to be turned into upscale apartments, cafes, and shopping centers meanwhile those unlucky enough to have been turned-out initially have either been relocated to housing projects well over an hour outside the city center. Though remaining residents have organized to slow the seizure of the rest of their property, the destruction of the Tarlabasi is allbut-inevitable; a "captive of urban geography", the community trapped here in social exclusion is now being directly preyed upon by expropriation practices from without and growing internal violence as the situation becomes more desolate (Burdett, 51-53).

Built in and around Istanbul's decaying industrial ring, slummification has been split between continued informal construction and state-sponsored housing projects - both of which have served to house people displaced internal to the city due to urban renewal projects as well as new arrivals from rural Anatolia (Bartu and Canden, 17). Within the context of this state mediated push towards large-scale redevelopment through the commodification of land, over half of the available housing stock within the city to date has been marked for demolition. While organized by municipal governments and funded by development firms - the largest of which being TOKI - the demolition process often targets entire neighborhoods at once, be they gecekond $u$ or dilapidated $19^{\text {th }}$ or $20^{\text {th }}$ century houses, in order to convert them to the new middle class standard. This mechanism of residential gentrification has been further facilitated by the central government since the catastrophic earthquake of 1999, after which it was decided that any structure that could be deemed unsound or otherwise unsafe was available for expropriation (Bartu and Canden, 16).

The veritable socio-spatial auto-cannibalism produced by the simultaneous slummification of neighborhoods belonging to the (polarized) poor and the gentrification of the 
same neighborhoods for the sake of promoting tourism and cosmopolitan culture alike is paralleled by the construction of massive buildings and complexes by star architects. These projects not only require massive demolitions which fracture the extant urban fabric, but in doing so produce a particular fragmentation of the city-body by rerouting traffic, reorienting consumption patterns, spatially isolating the new bourgeoisie, and privatizing available public space. Identified in the Runstand report as taking shape largely in gated, garden communities or - for the extremely wealthy - in "starchitect" projects such as the Zaha Hadid complex on the Sea of Marmara, these compounds are similarly located at the urban periphery; however, by virtue of their private ownership constitute an entirely separate trend towards intentional selfsegregation by those who can afford it. These gated garden towns are significant for a number of reasons - among them the willing separation of the self from the city, the use of intensive surveillance and the positon of fear with which the wealthy hold Istanbul's dense, urban centers, and the closing-in of the domestic sphere. That said, in conversation with the trends towards the constructions of commercial megamalls within the city's commercial and financial centers, the proliferation of these gated suburbs points to the broader trend of the privatization of public spaces once delegated for leisure or collective use.

In their direct relationship to both the democratic process and the built environment, the Taksim-Gezi Park protest movement occurred at the particular nexus of the myriad discourses discussed above. Beginning on May 28, 2013 as a sit-in organized by a student environmentalist organization in opposition to a redevelopment program for Taksim square that would have had Gezi bulldozed in order to repurpose the land towards the construction of another luxury mall, the movement quickly became a nation-wide event as videos of escalating police violence against protesters - resulting in the injury of thousands, as well as multiple deaths - spurred 
parallel protests in nearly a hundred other cities. While the original intention of the organizers may have more closely reflected the issues present in other "right to the city" movements, the movement came to encompass concerns over state violence, freedoms of speech and assembly, and freedom of press and intentional public disinformation which far transcended Istanbul's limits.

While the Gezi movement may have failed to produce a political coalition capable of standing in the way of Turkey's trend towards outright authoritarianism, it constituted the most powerful reassertion of the positon of the left and the youth within the proverbial ring of competing imaginations of Istanbul, Turkey, and the citizen's relationship in and to both. Moreover, the movement challenged directly the accelerating processes by which the will of the people is being systemically side-lined in order to better facilitate capital accumulation as has been the case under neoliberal development policy. Furthermore, that this movement emerged directly from concerns over the process by which the environment is built (or destroyed) posits the movement as one for serious consideration and further study within the context of the narrative and institutional production of territorialized place. Furthermore, given the similarities between the conditions of contemporary Istanbul and other megacities within the Global South, it does not seem far-fetched to wonder if mass mobilizations as they are sure to come will reflect similar concerns. Speculation aside, if it is acknowledged that the socio-spatial conditions within the (post)modern cosmopolis are the product of geographies of capital accumulation, then the case presented here of the intersections between these and geographies of (post)colonial and (post)imperial violence are themselves rife with the potential for instability and - as has been the case in other cities within the Middle East during the last decade - mass mobilization. 


\section{Concluding Remarks: Ending at the Beginning}

Less than 12 hours after the first draft of this thesis was submitted for review, votes were tallied in Ankara on a national referendum which - having passed by less than a $2 \%$ margin of difference- signals the first major reform to the structure of Turkey's government since its establishment as a Republic. In transforming the state apparatus from a parliamentary democracy to a presidential democracy, this passing of this referendum has eliminated the office of the prime minister and established the president as both head of state and chief member of the executive branch - the direct and immediate results of which are the dramatic expansion of presidential power. With this change, President Recip Tayyep Erdogan will be able to remain in office until 2029. What this means for Turkey's future no one - save, maybe, President Erdogancan say; however, given the nation's recent history of state violence against minority groups and top-down neoliberal economic and material development, all signs seem to point to the continued acceleration of these trends. Moreover, given the personal attention devoted to Istanbul during Erdogan's tenure in political office thus far, it seems as though the city will see the full force of this constitutional change with particular clarity and in particular focus.

The thesis project has attempted to synthesize and apply a framework for analyzing the cultural production of place, space, and identity therein within the context of the (post)colonial and (post)imperial conditions of the Global South as they continue to relate to the production of the present. In asserting that there exists a dialectic relationship between the social and the spatial mediated at the narrative level by ideology and the concrete by law, the case of the materialization of contemporary Istanbul has explore the modes, means, and methods by which these forces work to co-create both the material and imaginary faculties of the real. 
In exploring the influences of competing imaginations of the subject and the state as embodied within the city, this analysis has laid the groundwork for further study of Istanbul's contemporary moment as grounded within a history, landscape, and (human) geography characterized first and foremost by multiplicity. First through Orientalism, then through Nationalism, Capitalism, and Neoliberalism, the social, political, and material landscape of the city has changed throughout the last century to include layers of living memory of Istanbul and Turkey's (re)developments alike. Though without a doubt incomplete, this analysis of the condition of, in, and surrounding Istanbul as a territorial embodiment of the multitudinous competing imaginations of the city itself, of the Turkish citizen, and of the Turkish state within the context of self-conscious negotiation of their (post)imperial position within the European periphery. An attempt to synthesize a framework through which to approach the relationship between space, place, narrative, and power within the conditions of the (post)colonial, (post)imperial, and (post)modern contemporary, this thesis utilizes Spiro Kostof's "Organic" model of urban form to approach the city of Istanbul as the socio-spatial embodiment of a multitude of competing political imaginations of the state and the subject within modern Turkey. Beginning by establishing this theoretical framework, the majority of this piece discusses the relationship between prevailing narrative and ideological imaginations of the city and the material, legal, and social transformations thereby induced from the Tanzimat period to the present. In agreement with prior postcolonial, postimperial, and postmodern theories of geography, this analysis posits that place, space, and identity within contemporary Istanbul are ideologically constituted and are, therefore, inherently dynamic. 


\section{Bibliography}

Abu-Lughod, Janet L. Before European hegemony: the world system AD 1250-1350. Oxford University Press, USA, 1991.

Althusser, Louis. "Ideology and ideological state apparatuses (notes towards an investigation)." The anthropology of the state: A reader 9, no. 1 (2006): 86-98.

Bartu Candan, Ayfer, Tanil Bora, Sema Erder, Ayse Oncu, Martin Stokes, Jenny White, and Yael Navaro-Yasin. Istanbul: between the global and the local. Edited by Caglar Keyder. Rowman \& Littlefield Publishers, 1999.

Bartu Candan, Ayfer, and Biray Kolluoglu. "Emerging Spaces of Neoliberalism: A Gated Town and a Public Housing Project in Istanbul.” New Perspectives on Turkey 39 (2008) 5-46

Bartu Candan, Ayfer. "Who owns the old quarters?." Istanbul between the global and the local, New York/Oxford, Rowman and Littlefield Publishers (1999): 31-45.

Bhabha, Homi K. The location of culture. routledge, 2012.

Bozdogan, Sibel. Modernism and nation building: Turkish architectural culture in the early republic. University of Washington Press, 2001.

Burdett, Richard. "Istanbul: city of intersections." (2009).

Crane, Howard. "The Ottoman Sultan's mosques: Icons of imperial legitimacy." The Ottoman City and Its Parts: Urban Structure and Social Order (1991): 173-243.

Çelik, Zeynep. The remaking of Istanbul: portrait of an Ottoman city in the nineteenth century. No. 2. Univ of California Press, 1993.

Deleuze, Gilles. Anti-oedipus. A\&C Black, 2004.

Deleuze, Gilles, and Felix Guattari. "A thousand plateaus." (1987).

Dossik et. Al. "The Conflicted City: Hypergrowth, Urban Renewal, and Mass Urbanization in Istanbul” Seattle: Runstad Center for Real Estate Studies. 2012.

Dumont, Paul. "Ataturk and the Modernization of Turkey." Atatürk and the modernization of Turkey (1984).

Eisenstadt, Shmuel N. "The Kemalist Regime and Modernization: Some Comparative and Analytical Remarks." Atatürk and Modernization of Turkey (1984): 35. 
Eldem, Edhem, Daniel Goffman, and Bruce Masters. The Ottoman City between East and West: Aleppo, Izmir, and Istanbul. Cambridge University Press, 1999.

Fanon, Frantz. Black skin, white masks. Grove press, 2008.

Foucault, Michel. Discipline \& punish: The birth of the prison. Vintage, 2012.

Foucault, Michel. "The history of sexuality: An introduction, volume I." Trans. Robert Hurley. New York: Vintage (1990).

Gül, Murat. Emergence of Modern Istanbul: Transformation and Modernisation of a City. IB Tauris, 2009.

Harvey, David. Cosmopolitanism and the Geographies of Freedom. Columbia University Press, 2013.

Harvey, David. "The condition of postmodernity: An enquiry into the origins of social change." Malden, MA: Blackwell (1989).

Hooks, Bell. Representing whiteness in the black imagination. New York: Routledge, 1992

Jacobs, Jane M. Edge of empire: Postcolonialism and the city. Routledge, 2002.

Kandiyoti, Deniz, ed. Women, Islam and the state. Philadelphia: Temple University Press, 1991.

Cleveland, William L., and Martin Bunton. A history of the modern Middle East. Westview Press, 2016.

Karataşl1, Şahan Savaş. "The Origins of Turkey's "Heterodox" Transition to Neoliberalism: The Özal Decade and Beyond." Journal Of World-Systems Research 21, no. 2 (Summer/Fall2015 2015): 387-416. SocINDEX with Full Text, EBSCOhost (accessed April 15, 2017).

Kaya, Ibrahim. Social theory and later modernities: the Turkish experience. Oxford University Press, 2004.

Kostof, Spiro. The city shaped: Urban patterns and meanings through history. Thames and Hudson, 1991.

Lowry, Heath W. The nature of the early Ottoman state. SUNY Press, 2003.

Mango, Cyril. "The Urbanism of Byzantium Constantinople." Rassegna,(Istanbul, Constantinople, Byzantium) 72 (1997): 16-24

Mohanty, Chandra Talpade. "Under Western eyes: Feminist scholarship and colonial discourses." Feminist review 30 (1988): 61-88. 
Navaro-Yasin, Yael. "The Historical Construction of Local Culture." Istanbul: between the global and the local (1999): 59.

Necipoğlu, Gülru. "Challenging the past: Sinan and the competitive discourse of early modern Islamic architecture." Muqarnas 10 (1993): 169-180.

Neyzi, Leyla. "Object or Subject? The Paradox of "Youth" in Turkey." International Journal of Middle East Studies 33, no. 3 (2001): 411-32. http://www.jstor.org/stable/259458.

Öncü, Ayşe. "Istanbulites and Others." Istanbul: Between the global and the local (1999): 95119.

Parshad, Vijay. "In the Ruins of the Present: Neoliberalism and Cruel Populism Suffocate the Future." Lecture, University of Virginia Woodrow Wilson Department of Politics, Charlottesville, VA, April 7, 2017

Peirce, Leslie. Morality tales: Law and gender in the Ottoman court of Aintab. Univ of California Press, 2003.

Peirce, Leslie. "The imperial harem." Women and Sovereignty in the Ottoman Empire, New York-Oxford (1993): 242.

Pope, Nicole, and Hugh Pope. Turkey unveiled: A history of modern Turkey. Overlook Books, 2000 .

Singer, Amy. Constructing Ottoman beneficence: An imperial soup kitchen in Jerusalem. SUNY Press, 2012.

Said, Edward W. Culture and imperialism. Vintage, 2012.

Said, Edward. "Orientalism. 1978." New York: Vintage 1994 (1979).

Shami, Seteney, and Cynthia Miller-Idriss. Middle East Studies for the New Millennium: Infrastructures of Knowledge. NYU Press, 2016.

Soja, Edward W. "The Socio-Spatial Dialectic." Annals of the Association of American Geographers 70, no. 2 (1980): 207-25. http://www.jstor.org/stable/2562950.

Spivak, Gayatri Chakravorty. "Can the subaltern speak?." Can the subaltern speak? Reflections on the history of an idea (1988): 21-78.

Tezcan, Baki. "The Second Ottoman Empire." Political and Social Transformation in the Early Modern World. Cambridge (2010).

Wallerstein, Immanuel. World-systems analysis. 1987. 
Watts, Michael J. "Mapping meaning, denoting difference, imagining identity: dialectical images and postmodern geographies." Geografiska Annaler. Series B. Human Geography (1991): 7-16.

Woodard, Vincent, and Dwight McBride. The delectable Negro: Human consumption and homoeroticism within US slave culture. NYU Press, 2014.

Yerasimos, Stefanos. "Ottoman Istanbul."." Rassegna,(Istanbul, Constantinople, Byzantium) 19, no. 72 (1997): 25-35. 